\title{
Geochemical distribution and threshold values determination of heavy metals in stream water in the sub-basins of Vermelho and Sororó rivers, Itacaiúnas River watershed, Eastern Amazon, Brazil
}

\author{
Gabriel Negreiros Salomão ${ }^{1 *}$ \\ Roberto Dall'Agnol ${ }^{1}$ \\ Prafulla Kumar Sahoo ${ }^{1}$ \\ Jair da Silva Ferreira Júnior ${ }^{1}$ \\ Marcio Sousa da Silva ${ }^{1}$ \\ Pedro Walfir Martins e Souza Filho ${ }^{1}$ \\ José Francisco Berrêdo ${ }^{2}$ \\ Wilson da Rocha Nascimento \\ Junior \\ Marlene Furtado da Costa ${ }^{3}$ \\ ${ }^{1}$ Instituto Tecnológico Vale \\ Rua Boaventura da Silva, 955 \\ Belém, PA, Brasil \\ 66055-090 \\ ${ }^{2}$ Museu Paraense Emílio Goeldi (MPEG) \\ Avenida Perimetral, 1901 \\ Belém, PA, Brasil \\ 66077-530 \\ ${ }^{3}$ Gerência de Meio Ambiente - Minas de \\ Carajás/VALE \\ Departamento de Ferrosos Norte \\ Estrada Raymundo Mascarenhas, $\mathrm{S} / \mathrm{N}$ \\ Mina de N4 \\ Parauapebas, PA, Brasil \\ 68516-000 \\ Corresponding author: \\ gabriel.salomao@pq.itv.org
}

\begin{abstract}
RESUMO
Levantamento geoquímico nas sub-bacias Vermelho (SBV) e Sororó (SBS) da bacia do Itacaiúnas no sudeste da região Amazônica revela que parâmetros físicoquímicos da água superficial não mostram variações acentuadas entre as estações chuvosa e seca. Com exceção de $\mathrm{Fe}$ e $\mathrm{Mn}$, em geral os demais metais revelam baixas concentrações na água e não foram observadas evidências significativas de contaminação. Conteúdos comparativamente mais elevados foram obtidos principalmente durante a estação chuvosa. Fe e Mn se distribuem regularmente na água na área estudada e o aumento de seu conteúdo foi favorecido pelo desmatamento. A concentração de $\mathrm{Mn}$ aumenta durante a estação seca possivelmente devido a processos biogeoquímicos. Altas concentrações de $\mathrm{Fe} \mathrm{e}$ Mn em águas superficiais são inerentes às condições locais da região Amazônica. Fatores geogênicos influenciam a distribuição na água de $\mathrm{Co}, \mathrm{Cr}, \mathrm{Cu}, \mathrm{Ni}, \mathrm{Pb}, \mathrm{Sn}$, $\mathrm{V}$ e Zn. Efeitos antrópicos são subordinados, exceto para Fe e $\mathrm{Mn}$ ou em áreas localizadas. A definição de valores de threshold para $\mathrm{As}, \mathrm{Co}, \mathrm{Cr}$ e $\mathrm{Pb}$, apresentou limitações. Valores de threshold puderam ser definidos em pelo menos uma estação nas duas sub-bacias para $\mathrm{Cu}, \mathrm{Ni}, \mathrm{Sn}, \mathrm{V}$ e $\mathrm{Zn}$. No caso de $\mathrm{Fe}$ total, foram obtidos valores de threshold de 5 a $6 \mathrm{mg} / \mathrm{L}$ e de 2 a $3 \mathrm{mg} / \mathrm{L}$ nas estações chuvosa e seca, respectivamente. Os valores de threshold para Mn são de 0,30 a 0,45 mg/L na estação chuvosa e, na estação seca, decrescem para 0,20 a $0,30 \mathrm{mg} / \mathrm{L}$ na VSB e aumentam para 1,3 a $1,4 \mathrm{mg} / \mathrm{L}$ na SSB.

Palavras-chave: Geoquímica de água fluviais; Valores de threshold; Metais pesados; Bacia do rio Itacaiúnas; Amazônia Oriental.
\end{abstract}

\section{ABSTRACT}

Geochemical survey in the Vermelho (VSB) and Sororó (SSB) sub-basins of the Itacaiúnas basin in southeastern Amazonian region has shown that the physicalchemical parameters of stream water do not display accentuated variations between the rainy and dry seasons. Except for Fe and Mn, in general most metals show low contents in water and evidences of significant contamination were not observed. Higher contents were mostly registered during the rainy season. Fe is regularly distributed in water in the studied area and the increase of its concentration was favored by deforestation. Mn contents increase during the dry season possibly due to biogeochemical processes. High $\mathrm{Fe}$ and $\mathrm{Mn}$ contents in water are inherent to the specific local conditions prevalent in the Amazonian region. Geogenic influence in metal distribution in water is significant for $\mathrm{Co}, \mathrm{Cr}$, $\mathrm{Cu}, \mathrm{Ni}, \mathrm{Pb}, \mathrm{Sn}, \mathrm{V}$, and $\mathrm{Zn}$. Anthropic effects are subordinate except for $\mathrm{Fe}$ and $\mathrm{Mn}$ or in local areas. The definition of threshold values for $\mathrm{As}, \mathrm{Co}, \mathrm{Cr}$, and $\mathrm{Pb}$, was limited, however, threshold values for $\mathrm{Cu}, \mathrm{Ni}, \mathrm{Sn}, \mathrm{V}$, and $\mathrm{Zn}$ were estimated for at least one season in each sub-basin. Threshold values of total iron were obtained ( 5 to $6 \mathrm{mg} / \mathrm{L}$ and 2 to $3 \mathrm{mg} / \mathrm{L}$ in the rainy and dry seasons, respectively). Estimated Mn threshold values are 0.30 to $0.45 \mathrm{mg} / \mathrm{L}$ in the rainy season and in the dry season they decrease to 0.20 to $0.30 \mathrm{mg} / \mathrm{L}$ in VSB and increase to 1.3 to $1.4 \mathrm{mg} / \mathrm{L}$ in SSB.

Keywords: Stream water geochemistry, Heavy metals, Threshold limit values, Itacaiúnas River Watershed, Eastern Amazon. 


\section{INTRODUCTION}

Environmental monitoring surveys are increasing not only because of its inherent relevance, but also due to the availability of high standard analytic and computational facilities that allow quick responses (Tercier-Waeber et al. 2009, Wade et al. 2012, Aubert et al. 2014, Halliday et al. 2015, Girardi et al. 2016). Elemental concentrations in river waters are related to the local geologic setting but are also influenced by various other anthropogenic factors. Changes in land use and land cover can drastically influence natural hydrological regime and quality of stream water and water bodies (Brion et al. 2011, Souza-Filho et al. 2016, Levy et al. 2018). Comparisons of hydrological behavior and elemental concentrations in rivers with different land uses were reported by Neal et al. (2012), Wade et al. (2012) and Outram et al. (2014).

Particularly for toxic heavy metals, the determination of background values or threshold limits of elements is highly relevant to distinguish between natural and anthropogenically-influenced metal concentrations (Urresti-Estala et al. 2013, Arpine \& Gayane 2016). The imprecise use of the terms background and threshold and the statistical methods for their determination have been discussed (Ander et al. 2013, Cembranel et al. 2017, Gałuszka \& Migaszewski 2012, Gałuszka 2007, Matschullat et al. 2000, Nakić et al. 2007, 2010, Peh et al. 2009, Reimann \& Garrett 2005, Reimann et al. 2005, 2018, Rodrigues et al. 2013, Teng et al. 2009, Urresti-Estala et al. 2013, Zgłobicki et al. 2011). Geochemical background and threshold values are generally used as a reference to distinguish between natural concentrations of a certain element from the concentrations affected by anthropogenic activities, considering temporal and spatial variables of the area under investigation (Gałuszka 2007, Reimann \& Garrett 2005). Moreover, statistical methods for the determination of threshold values are a current discussion on literature (Reimann et al. 2005, 2018, Cembranel et al. 2017, Ander et al. 2013, Rodrigues et al. 2013, Nakić et al. 2007, 2010, Peh et al. 2009, Teng et al. 2009, Gałuszka 2007, Reimann et al. 2005, Reimann \& Garrett 2005, Matschullat et al. 2000).

Geochemical background surveys of many stream water have been widely conducted in many countries worldwide. However, in Brazil and particularly in the Amazon region, they are still scarce. To fulfill partially this gap of information, the Instituto Tecnológico Vale (ITV) is undertaking, at present, a systematic geochemical background survey in surficial water, stream sediments and soils in the Itacaiúnas River Watershed (IRW). In part of this area, previous geochemical surveys in soil and stream sediments were conducted by Companhia de Pesquisa de Recursos Minerais (CPRM - Brazilian Geological Survey, CPRM 2013, 2012) and Vale S/A (unpublished internal reports). A geochemical study of surface water samples in the Parauapebas area of the IRW was undertaken by the Museu Paraense Emílio Goeldi (MPEG) (Ruivo \& Sales 1989). The obtained results by MPEG team are of historical interest but their use is limited for the sampling criteria and analytical method adopted.

The present work is focused on the geochemistry and characterization of surficial water of the sub-basins of the Vermelho (VSB) and Sororó (SSB) rivers, located in the eastern domain of the IRW (Figure 1). This study is related to the Geochemical Background of the Itacaiúnas River Watershed (GBI) project, conducted by ITV. The study area was significantly influenced by land-use and land cover changes over the past decades (Souza-Filho et al. 2016), with accentuated expansion of pasturage and cattle production, development of mining projects, and growth of urban areas. As a consequence, the dispute for territory in the region has intensified and the quality of water resources became a serious concern. It is known that monitoring of stream water is an important step to evaluate its quality, to identify the nature and spatial distribution of eventual contaminants and to project environmental mitigation measures, if needed. This study aims to make a general water quality characterization and estimate threshold limit values of some heavy metals, identified as Potentially Toxic Elements (PTEs), in the stream water of the two mentioned sub-basins of IRW (VSB and SSB). This study will contribute to define the stream water geochemical characteristics and to establish a reference picture for it in the eastern domain of the IR.

\section{LOCATION AND GENERAL ASPECTS OF THE STUDY AREA}

The study area corresponds to the sub-basins of Vermelho and Sororó rivers located in the eastern IRW, North of Tocantins Basin (Figure 1).
The IRW is entirely located in the Carajás region, Pará state, north of Brazil, and the main city in the region is Marabá. The VSB and the SSB cover 
an area of 7,000 and $3,600 \mathrm{~km}^{2}$, respectively, and both represent approximately $25.6 \%$ of the IRW $\left(41,342 \mathrm{~km}^{2}\right)$. The towns of Curionópolis and Eldorado dos Carajás are situated in the study area (Figure 1).

The IRW was originally covered by the Amazon rainforest. However, it suffered intense changes in the land use and land cover, due to accelerated human occupation over the last decades. At present, areas covered by reminiscent tropical rainforest are mostly limited to environmental protected areas and indigenous lands (cf. Figures 1A and 2A) and pasturages are largely dominant. Pristine montane savanna covering ferruginous canga and urban areas are subordinated (Figure 1A; Souza-Filho et al. 2016). The region has a monsoon climate (Alvares et al. 2013) with a rainy season (November to April; Figure 2B) with precipitation average of $1,550 \mathrm{~mm}$, and a comparatively dry season (May to October; Figure 2C) with precipitation average of $350 \mathrm{~mm}$ (Silva Júnior et al. 2017).
Along the valleys of Vermelho and Sororó rivers, the relief of the region is flat with altitudes ranging mostly from 80 to $400 \mathrm{~m}$ (Figure 2D). It becomes more accentuated in the western part of the VSB, where hilly terrains, associated to highly dissected plateaus, with altitudes ranging from 400 to $780 \mathrm{~m}$, are present. Besides that, local highs are related to mafic-ultramafic intrusions in the central lower lands and to the units of the Parnaíba sedimentary basin, in the eastern border of the Sororó sub-basin.

The geology of the study area is marked by two main geological domains, the Carajás province, restricted to the western part of VSB, and the Araguaia Belt that corresponds to most of it (Figure 2E). The Carajás Province is an Archean domain located in the southeastern part of the Amazonian Craton (Vasquez et al. 2008, Almeida et al. 2011, Feio et al. 2013, and references therein) and it has a remarkable economic relevance due to its active mines of iron, copper (both world-class), manganese and nickel (Docegeo 1988, Moreto et al. 2014).

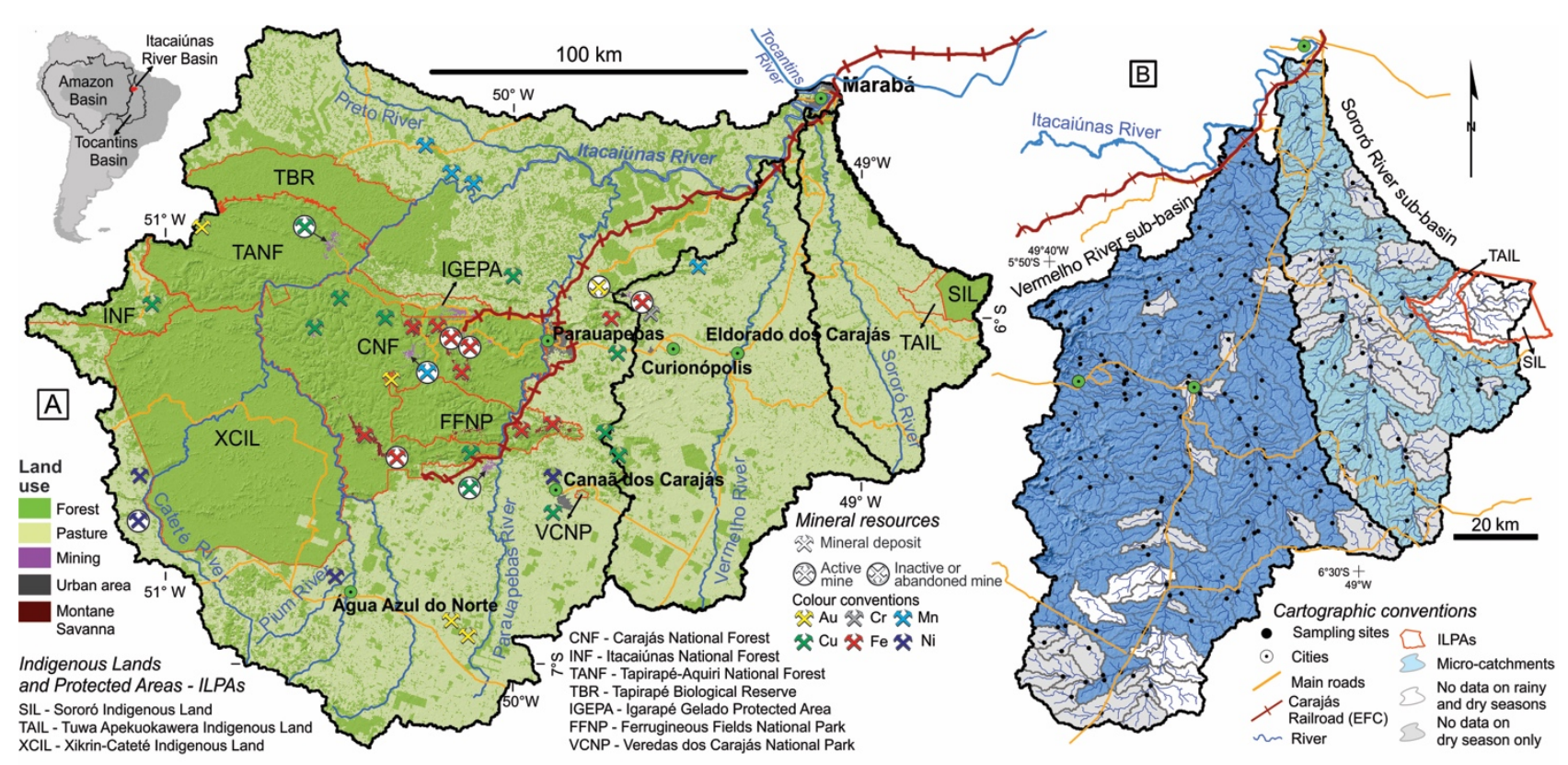

Figure 1

Map of the Itacaiúnas River Watershed in the region of Carajás, northern Brazil (A), highlighting the Vermelho and Sororó rivers subbasins. The location of main cities, mines, and mineral deposits, and the indigenous lands and protected areas are indicated, as well as main land uses. In the study area map (B), the individualized micro-catchments and the location of sampling sites for stream water are

shown.

In the Carajás Province, the main units are Mesoarchean calc-alkaline granites, tonalites and trondhjemites with subordinate gneisses and migmatites and local remnants of greenstone belts (Machado et al. 1991, Feio et al. 2013, Moreto et al. 2014). The granitoid basement is overlain by the Neoarchean Itacaiúnas Supergroup, which is represented by mafic-felsic volcanic sequences of the Grão Pará (Zucchetti \& Lobato 2004, Martins et al. 2017), and Rio Novo groups (Gibbs et al. 1986, Docegeo 1988, Machado et al. 1991, Vasquez et al. 2008). These units are crosscut by Archean syntectonic A-type like granitoids (Huhn et al. 1999, Barros et al. 2001, Sardinha et al. 2006, Feio et al. 2012, Dall'Agnol et al. 2017), layered mafic-ultramafic rocks (Machado et al. 
1991, Vasquez et al. 2008, Teixeira et al. 2015), and Paleoproterozoic anorogenic A-type granitic plutons (Teixeira et al. 2017). Paleoproterozoic clastic sedimentary rocks cover partially the Archean sequences of the study area (Araújo and Maia 1991, Nogueira et al. 1995).

In the Neoproterozoic Araguaia Belt, the lowgrade metasedimentary rocks of the Couto Magalhães Formation, composed mainly by phyllites and slates, interlayered with minor amounts of quartzite, meta-arkose and metalimestone (Gorayeb 1981, Hasui et al. 1984, Dall'Agnol et al. 1988), are dominant. The metamorphic grade increases towards east where it occurs the schists of the Pequizeiro Formation (Figure 2E). Metamafic-ultramafic bodies are found in the central-southern part of the VSB (Serra do Tapa and Quatipuru units; Vasquez et al. 2008). Paleozoic-Mesozoic sedimentary rocks related to the Parnaíba Basin occur in the extreme eastern part of SSB and in the north of the study area, represented by Itapecuru Group, Pimenteiras and Pedra de Fogo formations. Neogene sedimentary deposits of sand, clay and ferruginous crusts, are mainly located at the main water streams of the Vermelho and Sororó rivers.
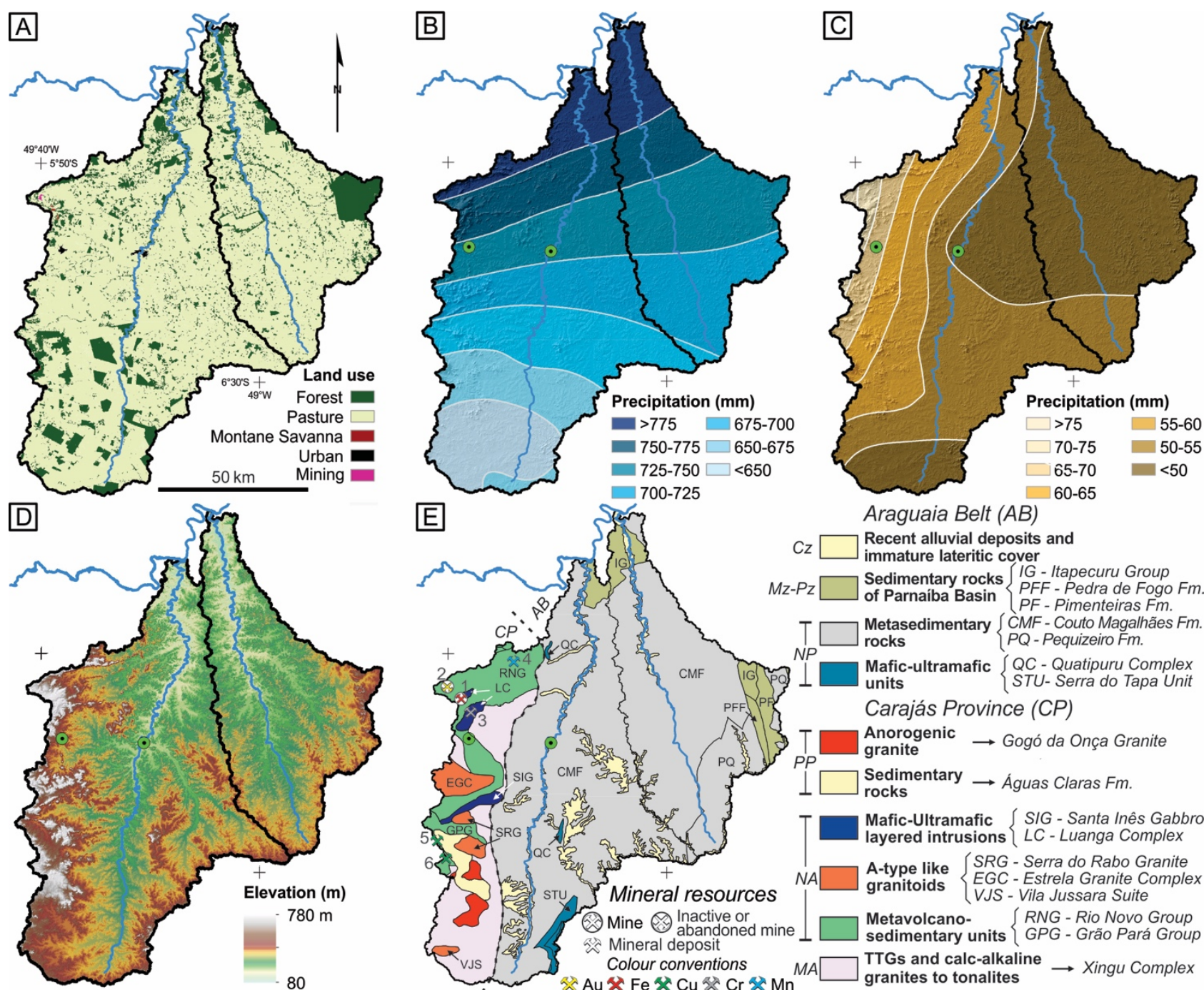

Araguaia Belt (AB)

$\mathrm{Cz}$ Recent alluvial deposits and immature lateritic cover
Sedimentary rocks $\begin{aligned} & \text { IG - Itapecuru Group } \\ & \text { of Parnaíba Basin }\end{aligned}$ PFF-Pedra de Fogo Fm
$P F-P$ - Pimenteiras Fm. immature lateritic cover
Sedimentary rocks $\begin{aligned} & \text { IG - Itapecuru Group } \\ & \text { of Parnaíba Basin }\end{aligned}$ PFF-Pedra de Fogo Fm
$P F-P$ - Pimenteiras Fm. Carajás Province (CP)

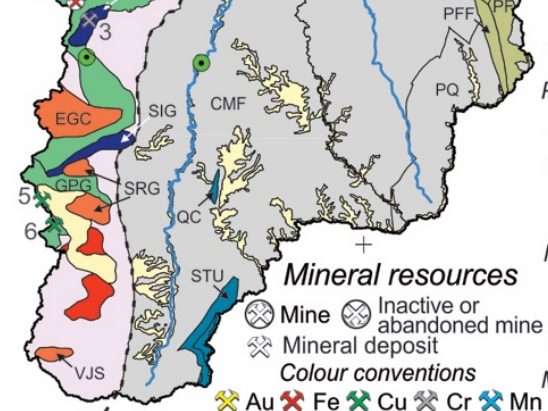

Anorogenic
granite Gogó da Onça Granite

Sedimentary $\rightarrow$ Águas Claras Fm.

Mafic-Ultramafic $\{$ SIG - Santa Inês Gabbro layered intrusions LC - Luanga Complex

A-type like SRG - Serra do Rabo Granite granitoids EGC - Estrela Granite Complex granitoids VJS - Vila Jussara Suite

Metavolcano- $\quad\{$ RNG - Rio Novo Group sedimentary units GPG - Grão Pará Group TTGs and calc-alkaline granites to tonalites

Figure 2

General aspects of the study area: A) Simplified land cover and land use map of the studied area in 2013 (Souza-Filho et al. 2016). Precipitation maps during (B) rainy season, from December to February, and (C) dry season, from June to August. (D) Hypsometric map derived from Shuttle Radar Topography Mission (SRTM) data of the United States Geological Survey (USGS). (E) Simplified geological map of the study area [based on Teixeira et al. (2017), Vasquez et al. (2008), Pimentel et al. (2004) and Alvarenga et al. (2000)], exhibiting the main lithostratigraphic units of the Archean Carajás Province (ACP) and Neoproterozoic Araguaia Belt (NAB).

Chronostratigraphic conventions: MA=Mesoarchean; NA=Neoarchean; PP=Paleoproterozoic; NP=Neoproterozoic; Pz=Paleozoic; Mz=Mesozoic; $\mathrm{Cz}=$ Cenozoic. Mines and mineral deposits: 1=Serra Leste active mine; 2=Serra Pelada abandoned mine; 3=Luanga; 4=Serra do Sereno; 5=Cristalino; $6=$ Serra Buriti. In figures 2 to 5, the crosses located at the left upper corner and at the lower right corner indicate the latitudes of $5^{\circ} 50^{\prime}$ and $6^{\circ} 30^{\prime}$ South and longitudes of $49^{\circ} 40^{\prime}$ and $49^{\circ}$ West, respectively (cf. Figure $1 \mathrm{~B}$ ). 


\section{MATERIALS AND METHODS}

\subsection{WATER SAMPLING: LOCATION AND METHOD}

Sampling method followed the procedures defined in the GBI project of ITV. Before sampling, the microbasins present in the entire area of the Itacaiúnas watershed were identified using remote sensing techniques. It was planned to collect one stream water sample in each microbasin, preferentially near the mouth of the tertiary water flow. In the whole Itacaiúnas basin around nine hundred sampling points were visited in each season. Two hundred and twenty-nine sites from that total are located in the eastern part of IRW in the domains of Vermelho and Sororó sub-basins (Figure 1B). Field works were undertaken in two distinct periods, during the rainy (March to April) and dry season (July to August), of 2017. In both seasons, a limited number of microbasins could not be sampled due to access conditions. These include the microbasins located in two indigenous lands of the Sororó Sub-basin (Figure 1B). During the dry season, this number increased significantly because of the intermittent character of part of the local drainage, in particular in the middle and high

\subsection{ANALYTICAL METHODS}

The analytical methods adopted for stream water samples were previously determined for the whole sample set of the BGI project. Five physico-chemical parameters $(\mathrm{pH}$, conductivity $\mathrm{EC}$, dissolved oxygen - DO, temperature, and redox potential - Eh) were measured in situ with a multiparameter probe (HI 98194 from Hanna Instruments ${ }^{\mathbb{B}}$ ), while TDS and turbidity were measured in the laboratory. The unfiltered water samples were acidified with $\mathrm{HNO}_{3}$ to $\mathrm{pH}<2$ at the time of collection and used to analyze total metal concentrations. The total content of twentyfour elements $(\mathrm{Ag}, \mathrm{Al}, \mathrm{As}, \mathrm{Ba}, \mathrm{Be}, \mathrm{Ca}, \mathrm{Cd}, \mathrm{Co}$, course of Sororó River and in the high course of Vermelho River. Duplicate samples were collected separately as additional samples immediately after the collection of the representative stream water samples at an approximate rate of one duplicate per each 20 samples collected.

Sampling and preservation of water samples were done following the Standard Methods for the Examination of Water and Wastewater (SMWW, methods 1060 and POP LB 010; APHA 2012). The samples were collected in the middle of the channel, in a location upstream from the collection point of the stream sediments. At each point, physico-chemical parameters were measured in situ with multi-parameter probe and two separated samples were then collected, the first to be stored in a $30 \mathrm{ml}$ high density polyethylene bottle (anions determination / nonpurgeable organic carbon - NPOC), and a second of $60 \mathrm{ml}$ high density polyethylene bottle (metal element analysis).

$\mathrm{Cr}, \mathrm{Cu}, \mathrm{Fe}, \mathrm{Hg}, \mathrm{K}, \mathrm{Mg}, \mathrm{Mn}, \mathrm{Mo}, \mathrm{N}, \mathrm{Na}, \mathrm{Ni}, \mathrm{Pb}$, $\mathrm{Se}, \mathrm{V}$, and $\mathrm{Zn}$ ) in water were analyzed by inductively coupled plasma mass spectrometry (ICP-MS), except for total P. Anions (fluoride, chloride, nitrate, and sulphate) were determined by ion chromatography. Table 1 summarizes information regarding analytical methods and sample preparation. All analytical procedures were undertaken by the certified laboratory Bioagri Ambiental Ltda. A summary of the analytical results and detection limits of these elements is shown in Table 2.

\subsection{GEOGRAPHIC INFORMATION SYSTEM AND SPATIAL ANALYSIS}

A specific geochemical database (BDGeoq) was structured by the team of the GBI project initially to guide sample location and store all field data using tablets and gradually additional related information as analytical results and geochemical maps. Programming rules were applied to avoid accidental errors in sampling registering and duplicate collection of samples in a same microbasin. After the conclusion of the project, the intention is to make the BDGeoq available for consultation of enabled users via an online geographic information system platform (SIGGeoq) (e.g., PostGIS or Quantum GISQGIS).

For the construction of geochemical maps, and also for other maps presented in this paper, the datum World Geodetic System 1984 (WGS84) was adopted. The delimitation of catchment areas was performed via algorithm-based analysis via QGIS software (Quantum GIS Development Team 2009), based on a digital elevation model (DEM) from Shuttle Radar Topography Mission 
(SRTM) conducted by the United States Geological Survey (USGS) (freely available online at https://earthexplorer.usgs.gov/). The contouring and coloring in the maps showing the distribution of elements were defined taking in account the analytical results above the detection limits for each element. The resulting intervals on both rainy and dry seasons are easily comparable.

Table 1 - Physico-chemical parameters and anions in surface water samples

\begin{tabular}{|c|c|c|c|c|c|}
\hline Parameters & $\begin{array}{r}\text { Detection } \\
\text { limit (DL) }\end{array}$ & Unit & $\begin{array}{c}\text { Specific } \\
\text { conditions }\end{array}$ & Method & $\begin{array}{c}\text { Maximum } \\
\text { holding time }\end{array}$ \\
\hline${ }^{1}$ Dissolved oxygen & 0.1 & $\mathrm{mg} / \mathrm{L}$ & \multirow{5}{*}{ In situ } & \multirow{6}{*}{ HI 98194 multiparameter probe } & \\
\hline${ }^{2} \mathrm{pH}\left(25^{\circ} \mathrm{C}\right)$ & 2 to 13 & - & & & \\
\hline${ }^{3}$ Temperature & - & ${ }^{\circ} \mathrm{C}$ & & & - \\
\hline${ }^{4}$ Specific electrical conductivity & 1.0 & $\mu \mathrm{S} / \mathrm{cm}$ & & & \\
\hline${ }^{5}$ Redox potential & - & $\mathrm{mV}$ & & & \\
\hline${ }^{6}$ Total Dissolved Solids (TDS) & 5.0 & $\mathrm{mg} / \mathrm{L}$ & \multirow{7}{*}{$\begin{array}{c}\text { Cooling at } \\
4^{\circ} \mathrm{C}\end{array}$} & & 7 days \\
\hline${ }^{7}$ Turbidity & 0.1 & NTU & & Nephelometric & - \\
\hline${ }^{8}$ Phosphorus total $\left(\mathrm{P}_{\text {total }}\right)$ & 0.01 & \multirow{5}{*}{$\mathrm{mg} / \mathrm{L}$} & & Sulfuric acid digestion at $\mathrm{pH}<2$ & 28 days \\
\hline${ }^{9}$ Nitrate $\left(\mathrm{NO}_{3}{ }^{-}\right)$ & 2.2 & & & \multirow{4}{*}{ Ion chromatography } & \\
\hline${ }^{9}$ Sulfate $\left(\mathrm{SO}_{4}{ }^{2)}\right.$ & 0.5 & & & & 28 days \\
\hline${ }^{9}$ Fluoride $\left(\mathrm{F}^{-}\right)$ & 0.05 & & & & \\
\hline${ }^{9}$ Chloride $\left(\mathrm{Cl}^{-}\right)$ & 0.5 & & & & 48 hours \\
\hline
\end{tabular}

Note: The analytical procedures were adopted accordingly to the SMWW methods (APHA 2012): $45000 \mathrm{G}^{1} ; 4500 \mathrm{H}+\mathrm{B}^{2} ; 2550$ $\mathrm{B}^{3} ; 2510 \mathrm{~B}^{4} ; 2580 \mathrm{~B}^{5} ; 2540 \mathrm{~A}, \mathrm{~B}, \mathrm{C}, \mathrm{D}, \mathrm{E}^{6} ; 2130 \mathrm{~B}^{7} ; 4500 \mathrm{P}^{-E^{8}}$; and to the EPA 300.0: 1993, 300.1: 1999, POP PA 032 - Rev. $12^{9}$.

\subsection{STATISTICAL ANALYSIS AND DETERMINATION OF THRESHOLD VALUES}

The simple substitution method (Keith et al. 1983) was applied for the replacement of analytical values below the detection limit $(<\mathrm{DL})$, similarly suggested by Reimann \& Caritat (2017). Descriptive statistics of element concentrations were determined, some before and after removing outliers detected by Grubb's test (Grubbs 1969). Physico-chemical parameters and metal concentration were exhibited via box plot representation in order to drive a better understanding of the overall data distribution. Threshold values were only determined according to the following statistical methods: The Median +
2 Median Absolute Deviation ( $\left.\mathrm{M}_{\mathrm{MAD}}\right)$, Tukey's inner fences (TIF), the cumulative probability (CP), the iterative $2 \sigma$ technique (I2 $\sigma$ ) and the calculated frequency distribution (DF). Regarding a better understanding on the overall description of these methods see Reimann et al. $(2005,2018)$, Reimann \& Caritat (2017), Cembranel et al. (2017), Ander et al. (2013), Urresti-Estala et al. (2013) and Nakić et al. (2007). Statistical analyses and calculations were carried out using $\mathrm{R}$ ( $\mathrm{R}$ Development Core Team 2008), Action Stat Pro (Equipe Estatcamp 2014) and the VB Background $^{\circledR}$ freeware (Nakić et al. 2007).

\section{RESULTS}

\subsection{PHYSICO-CHEMICAL PARAMETERS AND ANIONS}

Boxplots of physico-chemical parameters (temperature, dissolved oxygen, acidity, specific electrical conductivity, redox potential, total dissolved solids, and turbidity) and anions (fluoride, chloride and nitrate) were constructed separately for both Vermelho and Sororó subbasins (Figure 3). In addition the maximum standard values for fresh water quality of the contemplated in the Brazilian legislation (CONAMA 357/05) are also presented.

The averages of the measured temperature values in the studied sub-basins show a narrow range (Figure 3A). In VSB, when comparing the rainy and dry periods, the maximum, median and minimum temperatures decreased around $2 \pm 1{ }^{\circ} \mathrm{C}$ each, with a wider temperature oscillation in the dry period. In SSB, the minimum temperature variation is similar to that observed in VSB, whereas the maximum and median temperatures mildly increased (Figure 3A). However, right and left skewed outliers values were mainly observed in SSB during dry season. By disregarding these anomalous values, it is deduced that the temperature in the SSB is not really discordant of VSB (Figure 3A) and the overall dataset tends to a normal distribution. 
Table 2 - Descriptive statistics of stream water analyses of samples from Vermelho (VSB) and Sororó (SSB) sub-basins during rainy ($\mathrm{R})$ and dry (-D) seasons. $\mathrm{n}$ : number of samples; DL: detection limit; LOL: lower outlier limit; Min: minimum concentration; M: $50^{\text {th }}$ percentile of the data set, also known as median; and Max: maximum concentration. Mean ( $\sigma$ ) and standard deviation (SD) were calculated before (BRO) and after (ARO) removing outliers

\begin{tabular}{|c|c|c|c|c|c|c|c|c|c|c|c|c|c|c|c|}
\hline \multirow[t]{2}{*}{ Element } & \multirow{2}{*}{$\begin{array}{c}\text { SB - } \\
\text { Season }\end{array}$} & \multirow[t]{2}{*}{$\mathrm{n}$} & \multirow[t]{2}{*}{ DL } & \multirow[t]{2}{*}{$\mathrm{n}<\mathrm{DL}$} & \multirow[t]{2}{*}{$\%<\mathrm{DL}$} & \multirow[t]{2}{*}{ LOL } & \multirow[t]{2}{*}{$\mathrm{n} \geq \mathrm{LOL}$} & \multirow[t]{2}{*}{$\% \geq \mathrm{LOL}$} & \multirow[t]{2}{*}{ Min } & \multirow[t]{2}{*}{$\mathrm{M}$} & \multirow[t]{2}{*}{ Max } & \multicolumn{2}{|c|}{$\mathrm{BRO}$} & \multicolumn{2}{|c|}{ ARO } \\
\hline & & & & & & & & & & & & $\sigma$ & SD & $\sigma$ & SD \\
\hline \multirow[t]{4}{*}{ As } & VSB-R & 143 & 1 & 130 & 90.9 & 1.03 & 13 & 9.1 & $<1$ & $<1$ & 4.37 & 0.62 & 0.50 & 0.50 & 0 \\
\hline & VSB-D & 123 & 1 & 114 & 92.7 & 1.26 & 4 & 3.3 & $<1$ & $<1$ & 2.8 & 0.61 & 0.42 & 0.50 & 0 \\
\hline & SSB-R & 75 & 1 & 54 & 72.0 & 1.19 & 21 & 28.0 & $<1$ & $<1$ & 3.99 & 0.92 & 0.79 & 0.50 & 0 \\
\hline & SSB-D & 50 & 1 & 34 & 68.0 & 2.69 & 3 & 6.0 & $<1$ & $<1$ & 3.39 & 0.90 & 0.71 & 0.76 & 0.45 \\
\hline \multirow[t]{4}{*}{$\mathrm{Co}$} & VSB-R & 143 & 1 & 66 & 46.2 & 4.90 & 5 & 3.5 & $<1$ & 1.11 & 9.58 & 1.53 & 1.51 & 1.36 & 1.10 \\
\hline & VSB-D & 123 & 1 & 62 & 50.4 & 6.67 & 5 & 4.1 & $<1$ & $<1$ & 17.7 & 1.74 & 2.38 & 1.38 & 1.32 \\
\hline & SSB-R & 75 & 1 & 58 & 77.3 & 2.07 & 3 & 4.0 & $<1$ & $<1$ & 4.29 & 0.77 & 0.62 & 0.68 & 0.38 \\
\hline & SSB-D & 50 & 1 & 33 & 66.0 & 3.44 & 2 & 4.0 & $<1$ & $<1$ & 4.04 & 0.87 & 0.71 & 0.75 & 0.40 \\
\hline \multirow[t]{4}{*}{$\mathrm{Cr}$} & VSB-R & 143 & 1 & 82 & 57.3 & 3.94 & 15 & 10.5 & $<1$ & $<1$ & 32.7 & 1.85 & 3.45 & 0.99 & 0.76 \\
\hline & VSB-D & 123 & 1 & 86 & 69.9 & 1.76 & 20 & 16.3 & $<1$ & $<1$ & 85.7 & 2.38 & 8.84 & 0.63 & 0.29 \\
\hline & SSB-R & 75 & 1 & 30 & 40.0 & 4.64 & 2 & 2.7 & $<1$ & 1.24 & 11.6 & 1.49 & 1.53 & 1.30 & 0.90 \\
\hline & SSB-D & 50 & 1 & 42 & 84.0 & 1.07 & 8 & 16.0 & $<1$ & $<1$ & 37.8 & 1.57 & 5.42 & 0.50 & 0.00 \\
\hline \multirow[t]{4}{*}{$\mathrm{Cu}$} & VSB-R & 143 & 1 & 45 & 31.5 & 11.4 & 6 & 4.2 & $<1$ & 1.66 & 19.3 & 2.94 & 3.41 & 2.44 & 2.40 \\
\hline & VSB-D & 123 & 1 & 44 & 35.8 & 5.84 & 9 & 7.3 & $<1$ & 1.35 & 45.9 & 2.48 & 5.03 & 1.52 & 1.11 \\
\hline & SSB-R & 75 & 1 & 19 & 25.3 & 7.35 & 5 & 6.7 & $<1$ & 1.46 & 40.4 & 2.66 & 5.36 & 1.50 & 0.85 \\
\hline & SSB-D & 50 & 1 & 27 & 54.0 & - & 0 & 0 & $<1$ & $<1$ & 4.02 & 1.17 & 0.93 & 1.17 & 0.93 \\
\hline $\mathrm{Fe}$ & VSB-R & 143 & 0.02 & 0 & 0 & 9.45 & 5 & 3.5 & 0.82 & 3.56 & 19.1 & 3.99 & 2.44 & 3.63 & 1.45 \\
\hline & VSB-D & 123 & 0.02 & 0 & 0 & 7.73 & 4 & 3.3 & 0.36 & 1.55 & 16.3 & 2.27 & 2.18 & 1.98 & 1.37 \\
\hline & SSB-R & 75 & 0.02 & 0 & 0 & 11.90 & 2 & 2.7 & 1.81 & 4.28 & 14.9 & 4.54 & 1.92 & 4.30 & 1.22 \\
\hline & SSB-D & 50 & 0.02 & 0 & 0 & 5.53 & 3 & 6.0 & 0.57 & 1.94 & 7.12 & 2.27 & 1.40 & 2.01 & 0.95 \\
\hline $\mathrm{Mn}$ & VSB-R & 143 & 0.001 & 0 & 0 & 1.04 & 8 & 5.6 & 0.03 & 0.22 & 3.74 & 0.33 & 0.42 & 0.25 & 0.18 \\
\hline & VSB-D & 123 & 0.001 & 0 & 0 & 0.61 & 27 & 22.0 & 0.02 & 0.17 & 5.90 & 0.62 & 1.09 & 0.18 & 0.12 \\
\hline & SSB-R & 75 & 0.001 & 0 & 0 & 0.71 & 5 & 6.7 & 0.03 & 0.20 & 2.12 & 0.28 & 0.30 & 0.21 & 0.13 \\
\hline & SSB-D & 50 & 0.001 & 0 & 0 & 2.64 & 4 & 8.0 & 0.02 & 0.62 & 9.14 & 0.99 & 1.48 & 0.64 & 0.46 \\
\hline $\mathrm{Ni}$ & VSB-R & 143 & 1 & 53 & 37.1 & 6.25 & 15 & 10.5 & $<1$ & 1.51 & 16.8 & 2.40 & 2.88 & 1.57 & 1.24 \\
\hline & VSB-D & 123 & 1 & 56 & 45.5 & 5.01 & 11 & 8.9 & $<1$ & 1.09 & 20.7 & 1.88 & 2.72 & 1.20 & 0.88 \\
\hline & SSB-R & 75 & 1 & 14 & 18.7 & 5.25 & 1 & 1.3 & $<1$ & 1.61 & 5.25 & 1.68 & 0.87 & 1.63 & 0.77 \\
\hline & SSB-D & 50 & 1 & 31 & 62.0 & 11.2 & 1 & 2.0 & $<1$ & $<1$ & 11.2 & 1.15 & 1.59 & 0.94 & 0.66 \\
\hline$\overline{\mathrm{Pb}}$ & VSB-R & 143 & 1 & 103 & 72.0 & 2.70 & 2 & 1.4 & $<1$ & $<1$ & 9.21 & 0.83 & 0.86 & 0.76 & 0.46 \\
\hline & VSB-D & 123 & 1 & 110 & 89.4 & 1.07 & 13 & 10.6 & $<1$ & $<1$ & 3.65 & 0.65 & 0.51 & 0.50 & 0 \\
\hline & SSB-R & 75 & 1 & 36 & 48.0 & 6.57 & 2 & 2.7 & $<1$ & 1.13 & 9.52 & 1.28 & 1.34 & 1.09 & 0.69 \\
\hline & SSB-D & 50 & 1 & 43 & 86.0 & 1.0 & 7 & 14.0 & $<1$ & $<1$ & 1.69 & 0.62 & 0.31 & 0.50 & 0.00 \\
\hline Sn & VSB-R & 143 & 1 & 83 & 58.0 & 6.07 & 14 & 9.8 & $<1$ & $<1$ & 22.4 & 2.30 & 3.62 & 1.26 & 1.23 \\
\hline & VSB-D & 123 & 1 & 37 & 30.1 & 25.3 & 1 & 0.8 & $<1$ & 1.88 & 25.3 & 2.25 & 2.59 & 2.07 & 1.53 \\
\hline & SSB-R & 75 & 1 & 53 & 70.7 & 3.84 & 3 & 4.0 & $<1$ & $<1$ & 5.91 & 1.00 & 1.05 & 0.83 & 0.64 \\
\hline & SSB-D & 50 & 1 & 8 & 16.0 & 13.3 & 3 & 6.0 & $<1$ & 2.51 & 19.3 & 3.40 & 3.54 & 2.62 & 1.62 \\
\hline $\mathrm{V}$ & VSB-R & 143 & 1 & 53 & 37.1 & 7.58 & 8 & 5.6 & $<1$ & 1.66 & 18.9 & 2.19 & 2.42 & 1.75 & 1.42 \\
\hline & VSB-D & 123 & 1 & 48 & 39.0 & 5.80 & 10 & 8.1 & $<1$ & 1.42 & 31.1 & 2.24 & 3.62 & 1.46 & 1.09 \\
\hline & SSB-R & 75 & 1 & 14 & 18.7 & 5.20 & 2 & 2.7 & $<1$ & 1.52 & 8.67 & 1.72 & 1.19 & 1.58 & 0.77 \\
\hline & SSB-D & 50 & 1 & 31 & 62.0 & - & 0 & 0 & $<1$ & $<1$ & 2.89 & 0.92 & 0.63 & 0.92 & 0.63 \\
\hline $\mathrm{Zn}$ & VSB-R & 143 & 1 & 51 & 35.7 & 52.7 & 4 & 2.8 & $<1$ & 7.12 & 517.0 & 14.41 & 44.35 & 9.78 & 11.00 \\
\hline & VSB-D & 123 & 1 & 4 & 3.3 & 61.0 & 3 & 2.4 & $<1$ & 9.03 & 109.0 & 14.39 & 15.60 & 12.53 & 9.76 \\
\hline & SSB-R & 75 & 1 & 2 & 2.7 & 63.6 & 5 & 6.7 & $<1$ & 15.30 & 151.0 & 22.54 & 24.00 & 17.47 & 11.74 \\
\hline & SSB-D & 50 & 1 & 0 & 0 & 68.4 & 5 & 10.0 & 1.2 & 11.25 & 170.0 & 26.28 & 38.88 & 14.79 & 14.34 \\
\hline
\end{tabular}

Note: Concentration values of $\mathrm{Fe}$ and $\mathrm{Mn}$ are expressed in $\mathrm{mg} / \mathrm{L}$, and for the other elements in $\mu \mathrm{g} / \mathrm{L}$. Data below DL were replaced by $1 / 2$ of the DL value. Cd, Hg and Mo were not exhibited because they presented more than $98 \%$ of the overall data $<$ DL. '-' Value not applicable.

In general, in both sub-basins, except for a few lower outliers, $\mathrm{pH}$ values are higher than 6 (Figure 3C). Stream water tends to be more acidic during rainy than dry season, and VSB exhibited wider distribution of $\mathrm{pH}$ values in comparison to SSB. When comparing between rainy and dry periods, VSB and SSB showed increasing values for median and first and third quartiles in the dry season. The obtained values indicate a near neutral character for stream water of both sub- basins. High-pH values ( $>8.35$; alkaline water) are outliers and were reported during the rainy period in both sub-basins. Comparatively lower $\mathrm{pH}$ values $(<6,15$; acid to near neutral water $)$ correspond to outliers and extremes and were mostly reported during dry period, especially in SSB.

The specific electrical conductivity and total dissolved solids (TDS) show similar behavior. It is clear that, in a same period, the stream waters of 
the VSB tend to present higher and more variable values for both parameters in comparison to SSB (Figures 3G, H). When comparing the rainy and dry seasons in each sub-basin isolated, it is observed a similar picture for total dissolved solids, with higher and more variable values in the dry season for both, VSB and SSB. On the other hand, specific electrical conductivity shows also a larger variation interval in the dry season, but values obtained in the two seasons are superposed. Outliers of electrical conductivity are more common in VSB in both seasons, and TDS outliers are only observed in VSB (Figures 3G, $\mathrm{H})$. By removing outliers, VSB and SSB exhibited similar right-skewed conductivity distribution in both seasons.

Dissolved oxygen (DO) presents similar trend in both sub-basins during the rainy period, while in the dry period, VSB displays mostly higher values and a much larger variation of $D O$ in comparison to SSB (Figure 3B). DO in SSB has little variation when comparing to the rainy and dry periods, but boxplot indicates that lower

\subsection{DESCRIPTIVE STATISTICS OF HEAVY METALS}

In this study, only 11 elements (As, Co, Cr, $\mathrm{Cu}, \mathrm{Fe}, \mathrm{Mn}, \mathrm{Ni}, \mathrm{Pb}, \mathrm{Sn}, \mathrm{V}$, and $\mathrm{Zn}$ ) that presented substantial amount of analytical data $>$ DL will be discussed in detail, and $\mathrm{Cd}, \mathrm{Hg}$, and Mo ( $>98 \%$ of the overall data was $<$ DL) will not be considered. It can be observed that the proportion of values $<\mathrm{DL}$ is also high for $\mathrm{As}$ and $\mathrm{Pb}$, the latter mainly during the dry season (Table 2). For statistical analysis, values $<$ DL were replaced by $1 / 2$ DL. Table 2 summarizes the statistics of analytical results of stream water samples from VSM and SSB during the rainy and dry seasons.

The boxplots for the 11 mentioned elements (Figure 4) show some relevant aspects: (1) As, $\mathrm{Co}, \mathrm{Cu}, \mathrm{Ni}, \mathrm{Pb}, \mathrm{Sn}$, and $\mathrm{V}$, do not present any result exceeding the maximum tolerated limits as defined by CONAMA 357/05. (2) Cr and $\mathrm{Zn}$ both have only one result corresponding to extreme outlier values above that limit and the anomalous $\mathrm{Cr}$ value was obtained in an area in the proximities of the Quatipuru mafic-ultramafic unit. (3) Independent of the period of the year, Mn behavior is entirely distinct from those of the

\subsection{SPATIAL DISTRIBUTION OF HEAVY METALS}

The spatial distribution of nine selected elements in VSB and SSB is shown in Figure 5. Arsenic and $\mathrm{Pb}$ were not illustrated because on an average they show more than $70 \%$ of results $<\mathrm{DL}$ (Table 2). Cobalt and $\mathrm{Cr}$ also show a large number values are dominant in the interval Q1-Q3 and the median value is significantly lower compared to that of the raining season (Figure 3B).

When evaluating the turbidity, it is clear that stream water in VSB and SSB presents substantially higher turbidity values during the rainy season in comparison to the dry period (Figure 3D). Moreover, SSB has a little higher turbidity during the rainy period in comparison to $\mathrm{VSB}$, contrasting with the dry season when the reverse is observed. Outliers and extremes are far more common in VSB than in SSB (Figure 3D).

In regard to the analyzed anions, in both subbasins, Chloride $\left(\mathrm{CI}^{-}\right)$and Fluoride $\left(\mathrm{F}^{-}\right)$show similar patterns than specific electrical conductivity and TDS (Figure 3H, I and J). For nitrate $\left(\mathrm{NO}_{3}{ }^{-}\right)$, few analyses presented values above the detection limit. VSB tends to have higher concentrations of nitrate in comparison to SSB. Moreover, VSB exhibited higher concentrations during the rainy season compared to the dry period (Figure 3K).

previous elements. It displays dominance of values above the maximum of CONAMA 357/05, with median, $25^{\text {th }}$ and $75^{\text {th }}$ quartiles values being higher than it. (4) In the case of total Fe, there is no reference value by CONAMA 357/05, but the Fe contents in water are high (median values $>$ $1.50 \mathrm{mg} / \mathrm{L}$; minimum values $>0.35 \mathrm{mg} / \mathrm{L}$; maximum values attaining 7.12 to $19.1 \mathrm{mg} / \mathrm{L}$; Table 2). It can be concluded that $\mathrm{Fe}$ contents in water are elevated and its behavior is similar in this perspective to $\mathrm{Mn}$.

Contents of most elements, including $\mathrm{Cr}, \mathrm{Cu}$, $\mathrm{Fe}, \mathrm{Ni}, \mathrm{Pb}$, and $\mathrm{V}$, decrease in water in the dry season compared to the rainy one in both VSB and SSB (Table 2, Figure 4). On the contrary, Sn contents in water increase in both sub-basins during the dry season. Mn contents increase in the dry season in the SSB and decrease in the VSB and $\mathrm{Zn}$ shows an opposite behavior. In general, there is a tendency to higher metal content in water during the rainy season. In the SSB, Fe and Mn show distinct behavior.

of results $<$ DL (Table 2) and this can be seen in the corresponding geochemical maps (Figure 5). In general, the higher contents of most metals in water during the rainy season is indicated by the contrast between the corresponding geochemical 

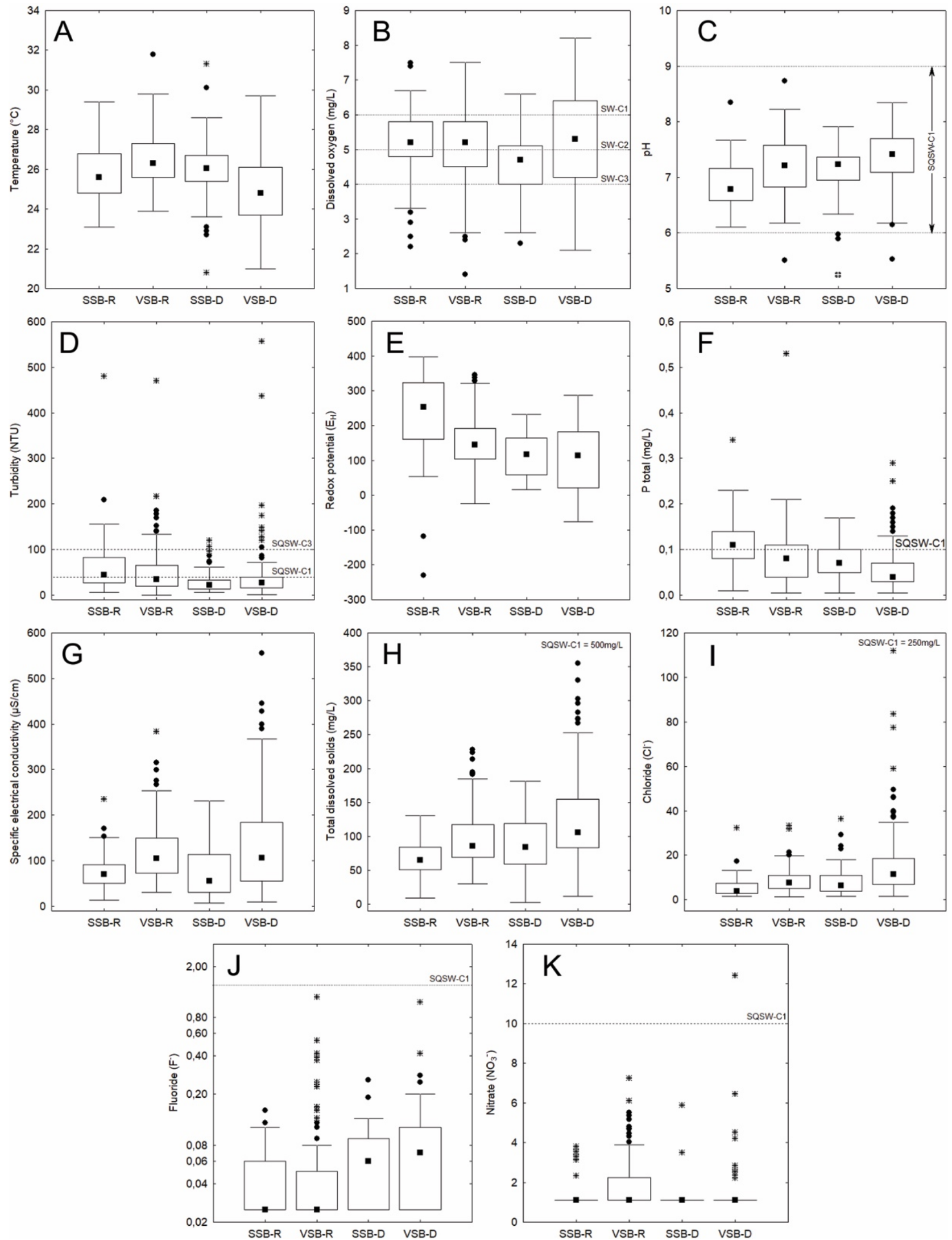

Boxplots of main physico-chemical parameters in stream water of Sororó (SSB) and Vermelho (VSB) sub-basins, analyzed during rainy $(-R)$ and dry (-D) seasons: Temperature (A); dissolved oxygen (B); $\mathrm{pH}(C)$; turbidity (D); redox potential (E); $P$ total $(F)$; specific electrical conductivity $(\mathrm{G})$; total dissolved solids $(\mathrm{H})$; and anions: chloride (I) fluoride $(\mathrm{J})$; and nitrate $(\mathrm{K})$. Dashed line represents standard quality for sweet water (SQSW) based in CONAMA 357/05 and the reference class is indicated. The box indicates approximately the 25th, 50th (median=black square) and 75th percentile; outliers are defined according to: (upper whisker, lower whisker) = (upper hinge, lower hinge) $\pm 1.5^{*}$ hinge width. Filled circles and asterisks represents respectively outliers and extremes. 

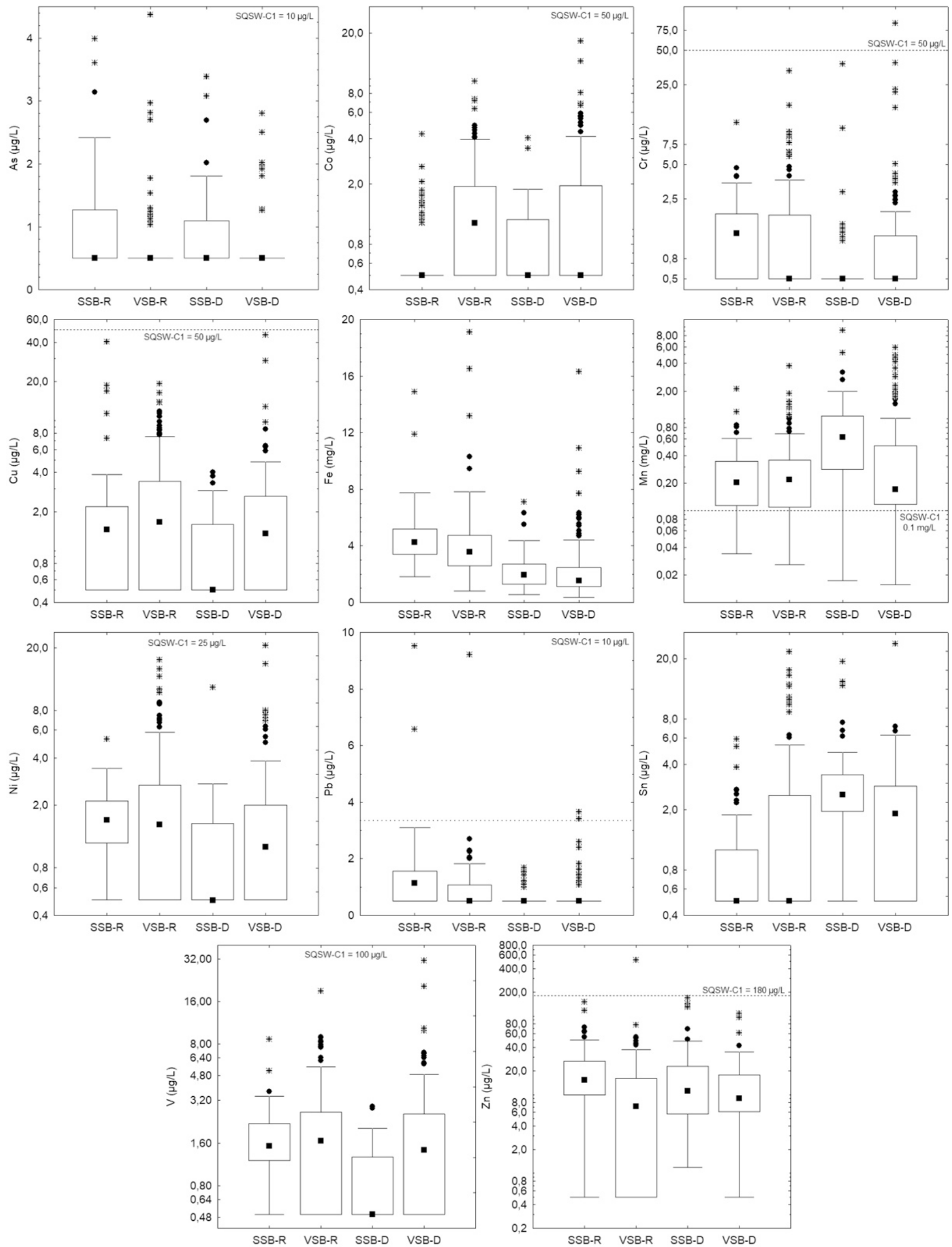
seasons. Standard quality for sweet water (SQSW) is given or represented by dashed lines and are based in CONAMA 357/05 for the reference classes indicated. The box indicates approximately the 25th, 50th (median=black square) and 75th percentile; outliers are defined according to: (upper whisker, lower whisker) $=$ (upper hinge, lower hinge) $\pm 1.5^{*}$ hinge width. Filled circles and asterisks represents respectively outliers and extremes. 
maps and those for the same metals in the dry season. Some metals, as exemplified by $\mathrm{Cu}, \mathrm{Ni}$, $\mathrm{Co}$, and $\mathrm{V}$, tend to be more abundant in the area situated on or under influence of the Amazonian craton. In some cases, the geochemical imprint of local geological setting is also evident, e.g. the preferential relationships of copper and cobalt with metavolcanosedimentary units and Cristalino deposit, as well as of nickel, chromium and vanadium with mafic-ultramafic units. The areal distribution and higher anomalous values of $\mathrm{Sn}$ in the raining season could be apparently related to the occurrences of A-type granites (Gogó-da-

\subsection{THE ESTABLISHMENT OF THRESHOLD VALUES}

Calculation of threshold values for metal contents in stream water of the Vermelho (VSB) and Sororó (SSB) sub-basins is strongly dependent of the number of analytical results larger than DL for each element (Table 3).

For those elements with dominance of $<\mathrm{DL}$ values, the statistical methods are generally not able to define a strict value for threshold. This is the case for $\mathrm{As}, \mathrm{Co}, \mathrm{Cr}$, and $\mathrm{Pb}$ that presented none or only few significant statistical values for threshold. These elements show also variations in the two sub-basins and in the seasons of the year. Arsenic data do not allow definition of threshold values, except for SSB during the dry season by TIF method which indicated a threshold value for it $<1 \mu \mathrm{g} / \mathrm{L}$, the DL value. For Co, the picture is a little distinct because it shows a clear contrast between the VSB and SSB with significant threshold values in the former during both seasons. The statistical data available allow to estimate threshold values of 2 to $4 \mu \mathrm{g} / \mathrm{L}$ for this element in the VSB and $<1 \mu \mathrm{g} / \mathrm{L}$ in the SSB. The geochemical contrasts between VSB and SSB are almost certainly related to the influence of geological setting and obtained results put in evidence that this is an essential aspect to be considered for threshold or background definition (Galuszka 2007, Reimann \& Garrett 2005, Reimann et al. 2005, Matschulat et al. 2000). In the case of $\mathrm{Cr}$, statistical data are consistent only for SSB during the raining season (Table 3) and suggest values of $\sim 3 \mu \mathrm{g} / \mathrm{L}$ for threshold in stream water. In VSB and during the dry season in SSB, values of $<1 \mu \mathrm{g} / \mathrm{L}$ should be considered. The increase of threshold values in SSB (D) is apparently not related to the influence of maficultramafic units that are concentrated in the VSB (Figure 5) and there is not a clear explanation for it. Lead behavior is similar to that of $\mathrm{Cr}$ and $\mathrm{Co}$, with threshold values of $2-3 \mu \mathrm{g} / \mathrm{L}$ being estimated in both VSB and SSB during the rainy season
Onça, Estrela and Serra do Rabo granites, Figure 2E). However, they cannot be explained in this way in the dry season that shows higher values in the SSB, without any influence of the mentioned granites.

Spatial distribution of $\mathrm{Fe}$ and $\mathrm{Mn}$ in water of the VSB and SSB is relatively uniform compared to those of other studied metals and cannot be attributed to lithological control (Figure 5). It is not affected by the presence in the studied area of the remarkable tectonic limit between the Amazonian craton and the Araguaia Belt. Hence, it should be explained in other way.

whereas during the dry season it should be $<1$ $\mu \mathrm{g} / \mathrm{L}$.

Nickel and Sn results for threshold values are apparently better defined than for the previous metals, but they could be estimated only partially (Table 3). For Ni, threshold values are defined by different methods in the dry season in VSB and in the rainy season in SSB and can be estimated to be of 2-4 $\mu \mathrm{g} / \mathrm{l}$ (Table 3). For Sn, threshold values are better constrained in the dry season for VSB and SSB and can be estimated in 3-5 $\mu \mathrm{g} / 1$ (Table $3)$.

The five remainder metals, $\mathrm{Fe}, \mathrm{Mn}, \mathrm{Cu}, \mathrm{V}$, and $\mathrm{Zn}$ compared to those metals previously discussed show lower number of results $<$ DL (Table 2), thus they have been able to give significant threshold values in stream water, except for $\mathrm{Cu}$ and $\mathrm{V}$ during the dry season (Table 3 ). For $\mathrm{Cu}$, the methods CF, I2 $\sigma$ and DF indicate values of 2-3.5 $\mu \mathrm{g} / \mathrm{l}$ and for $\mathrm{V}$ between 2.0 and $3.0 \mu \mathrm{g} / \mathrm{l}$ (Table 3). For $\mathrm{Zn}$ the situation is more complex because, taking as reference the three mentioned methods, there are significant variations in threshold values between the raining and dry seasons, with variation of 18 to $23 \mu \mathrm{g} / 1$ and 24 to $32 \mu \mathrm{g} / \mathrm{l}$ in the raining season and 9 to $17 \mu \mathrm{g} / 1$ and 9 to $24 \mu \mathrm{g} / \mathrm{l}$ in the dry season, respectively in VSB and SSB (Table 3). Overall, values between 15 and $30 \mu \mathrm{g} / 1$ can be seen as a reasonable threshold limit for $\mathrm{Zn}$ in the studied area.

Concentrations of $\mathrm{Fe}$ and $\mathrm{Mn}$ do not show analytical data $<$ DL (Table 2). Thereby the estimation of threshold values for these elements is more consistent. The results obtained are similar for the different methods employed (Table 3), except for $\mathrm{Fe}$ and $\mathrm{Mn}$. In most cases, the methods I2 $\sigma$ and DF that removed outliers produced similar results and are generally admitted as more suitable for geochemical threshold and background estimation (cf. Raimann and Caritat 2017, Urresti-Estala et al. 2013). 


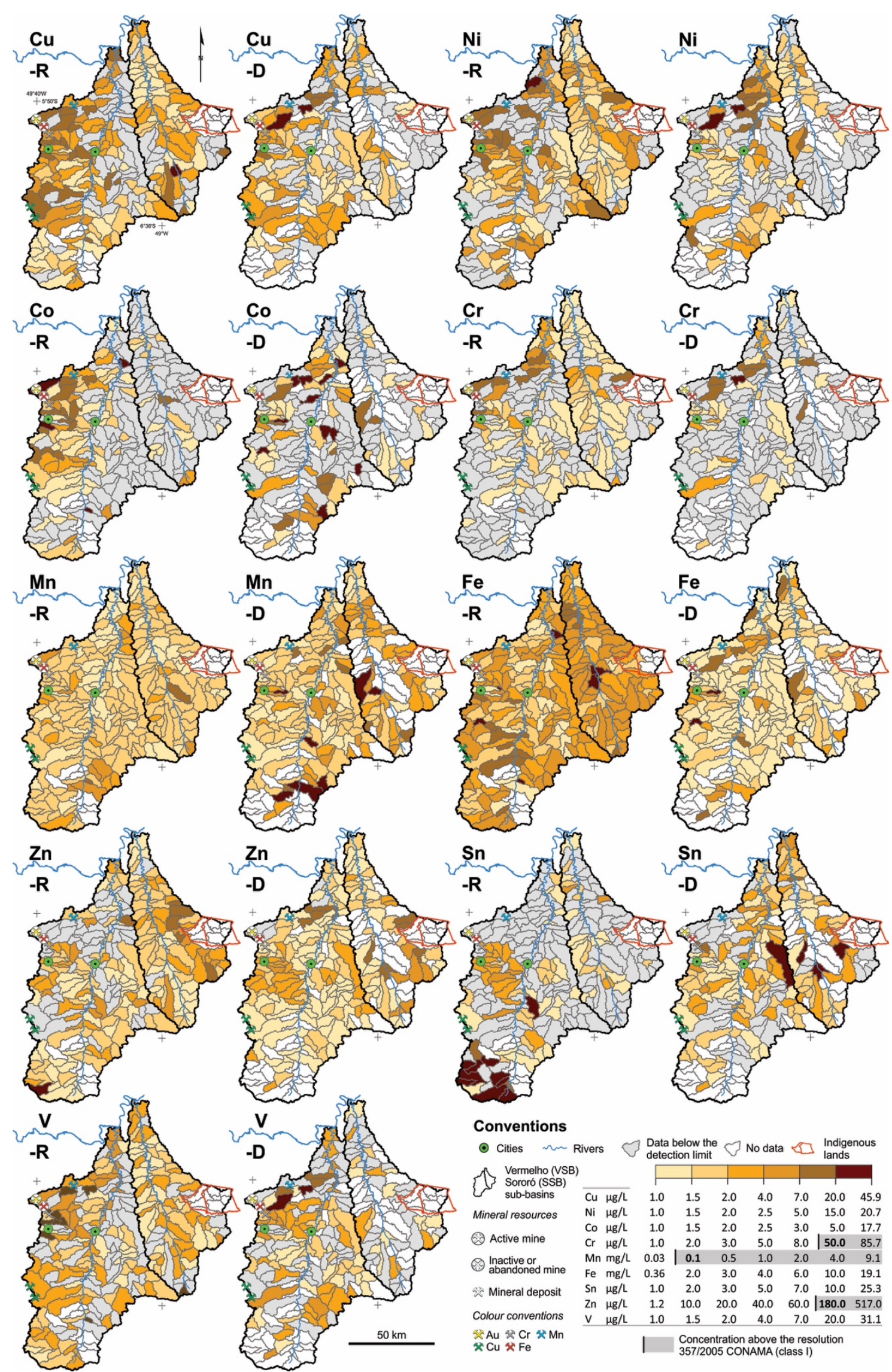

Figure 5

Geochemical distribution of $\mathrm{Cu}, \mathrm{Ni}, \mathrm{Co}, \mathrm{Cr}, \mathrm{Mn}, \mathrm{Fe}, \mathrm{Sn}, \mathrm{Zn}$, and $\mathrm{V}$ in stream water of the Vermelho and Sororó sub-basins of the Itacaiúnas River Watershed. The samples were collected during rainy (-R) and dry (-D) seasons along 2017. Refer to Figure 2 for the remarks applied, and to Table 2 for the detection limit. 
Table 3 - Threshold values obtained from various statistical methods [Median + 2 MAD, Tukey's inner fences (TIF), cumulative probability (CP) distribution diagrams, iterative $2 \sigma$ technique (I2 $\sigma)$ and calculated distribution function (DF)] for 11 elements in stream water of the Vermelho (VSB) and Sororó (SSB) sub-basins during rainy (-R) and dry (-D) seasons of 2017.

\begin{tabular}{|c|c|c|c|c|c|c|c|c|c|c|c|c|c|}
\hline \multirow[t]{2}{*}{ Element } & \multirow{2}{*}{$\begin{array}{c}\text { SB - } \\
\text { Season }\end{array}$} & \multirow{2}{*}{$\begin{array}{l}\text { Regul. } \\
\text { SWC1 }\end{array}$} & \multicolumn{5}{|c|}{ Possible threshold values based on GBI data } & \multicolumn{6}{|c|}{ Number of exceedances above } \\
\hline & & & $\mathrm{M}_{\mathrm{MAD}}$ & TIF & $\mathrm{CP}$ & $\mathrm{I} 2 \sigma$ & DF & SWC1 & $\mathrm{M}_{\mathrm{MAD}}$ & TIF & $\mathrm{CP}$ & $\mathrm{I} 2 \sigma$ & DF \\
\hline \multirow[t]{4}{*}{ As } & VSB-R & 10 & $<1$ & $<1$ & - & - & - & 0 & 13 & 13 & - & - & - \\
\hline & VSB-D & & $<1$ & $<1$ & - & - & - & 0 & 9 & 9 & - & - & - \\
\hline & SSB-R & & $<1$ & - & - & - & - & 0 & 21 & - & - & - & - \\
\hline & SSB-D & & $<1$ & 2.00 & - & - & - & 0 & 16 & 4 & - & - & - \\
\hline \multirow[t]{4}{*}{$\mathrm{Co}$} & VSB-R & 50 & 2.68 & 3.80 & 2.31 & - & 2.28 & 0 & 22 & 12 & 24 & - & 25 \\
\hline & VSB-D & & $<1$ & 3.66 & 3.46 & - & - & 0 & 61 & 14 & 14 & - & - \\
\hline & SSB-R & & $<1$ & $<1$ & - & - & - & 0 & 17 & 17 & - & - & - \\
\hline & SSB-D & & $<1$ & 2.04 & - & - & - & 0 & 17 & 2 & - & - & - \\
\hline \multirow[t]{4}{*}{$\mathrm{Cr}$} & VSB-R & 50 & $<1$ & - & - & - & - & 0 & 61 & - & - & - & - \\
\hline & VSB-D & & $<1$ & - & - & - & - & 1 & 37 & - & - & - & - \\
\hline & SSB-R & & 3.28 & 3.66 & 1.59 & 1.94 & 2.57 & 0 & 5 & 4 & 23 & 16 & 10 \\
\hline & SSB-D & & $<1$ & - & - & - & - & 0 & 8 & - & - & - & - \\
\hline \multirow[t]{4}{*}{$\mathrm{Cu}$} & VSB-R & 50 & 4.62 & 7.45 & 3.56 & 1.47 & 3.56 & 0 & 28 & 16 & 33 & 76 & 33 \\
\hline & VSB-D & & 3.53 & 4.64 & 2.95 & 2.00 & 2.80 & 0 & 14 & 11 & 22 & 40 & 25 \\
\hline & SSB-R & & 3.46 & 4.36 & 2.6 & 2.61 & 2.82 & 0 & 6 & 5 & 12 & 12 & 12 \\
\hline & SSB-D & & $<1$ & 3.27 & - & - & - & 0 & 23 & 3 & - & - & - \\
\hline \multirow[t]{4}{*}{$\mathrm{Fe}$} & VSB-R & - & 6.50 & 7.87 & 6.22 & 5.74 & 5.95 & - & 10 & 5 & 10 & 15 & 13 \\
\hline & VSB-D & & 3.23 & 4.13 & 1.99 & 2.07 & 2.67 & - & 20 & 17 & 39 & 39 & 28 \\
\hline & SSB-R & & 6.93 & 7.89 & 5.16 & 6.21 & 6.57 & - & 3 & 2 & 24 & 6 & 4 \\
\hline & SSB-D & & 3.61 & 4.24 & 2.49 & 2.84 & 3.41 & - & 8 & 4 & 13 & 11 & 8 \\
\hline \multirow[t]{4}{*}{$\mathrm{Mn}$} & VSB-R & 0.1 & 0.50 & 0.66 & 0.44 & 0.37 & 0.44 & 112 & 20 & 14 & 24 & 33 & 24 \\
\hline & VSB-D & & 0.28 & - & 0.22 & 0.20 & 0.30 & 96 & 42 & - & 50 & 52 & 40 \\
\hline & SSB-R & & 0.42 & 0.50 & 0.22 & 0.31 & 0.40 & 60 & 12 & 7 & 35 & 19 & 14 \\
\hline & SSB-D & & 1.45 & 1.94 & 0.67 & 1.32 & 1.39 & 43 & 6 & 5 & 24 & 7 & 7 \\
\hline \multirow[t]{4}{*}{$\mathrm{Ni}$} & VSB-R & 25 & 3.65 & - & 4.36 & 1.88 & - & 0 & 25 & - & 18 & 54 & - \\
\hline & VSB-D & & 1.49 & 3.76 & 2.97 & - & 2.22 & 0 & 46 & 13 & 16 & - & 24 \\
\hline & SSB-R & & 2.90 & 3.58 & 1.81 & 3.10 & - & 0 & 6 & 1 & 33 & 2 & - \\
\hline & SSB-D & & $<1$ & 2.76 & - & - & - & 0 & 19 & 1 & - & - & - \\
\hline \multirow[t]{4}{*}{$\mathrm{Pb}$} & VSB-R & 10 & $<1$ & 1.90 & 1.82 & - & - & 0 & 40 & 7 & 7 & - & - \\
\hline & VSB-D & & $<1$ & - & - & - & - & 0 & 13 & - & - & - & - \\
\hline & SSB-R & & 2.48 & 3.08 & 1.60 & 1.87 & 2.37 & 0 & 5 & 4 & 16 & 11 & 6 \\
\hline & SSB-D & & $<1$ & - & - & - & - & 0 & 7 & - & - & - & - \\
\hline \multirow[t]{4}{*}{$\mathrm{Sn}$} & VSB-R & - & $<1$ & 4.05 & 6.28 & - & - & - & 60 & 22 & 12 & - & - \\
\hline & VSB-D & & 5.91 & 6.26 & 3.3 & 3.16 & - & - & 4 & 4 & 24 & 26 & - \\
\hline & SSB-R & & $<1$ & 1.87 & - & - & - & - & 22 & 9 & - & - & - \\
\hline & SSB-D & & 4.38 & 5.22 & 3.43 & 4.44 & 5.07 & - & 8 & 6 & 12 & 8 & 6 \\
\hline \multirow[t]{4}{*}{$\mathrm{V}$} & VSB-R & 100 & 4.47 & 5.13 & 2.12 & 2.31 & - & 0 & 16 & 11 & 42 & 41 & - \\
\hline & VSB-D & & 3.59 & 4.25 & 2.26 & 2.18 & 3.06 & 0 & 17 & 12 & 30 & 33 & 22 \\
\hline & SSB-R & & 2.75 & 3.34 & 2.08 & 2.79 & 2.83 & 0 & 6 & 4 & 20 & 6 & 6 \\
\hline & SSB-D & & $<1$ & 2.45 & - & - & - & 0 & 19 & 2 & - & - & - \\
\hline \multirow[t]{4}{*}{$\mathrm{Zn}$} & VSB-R & 180 & 25.00 & 37.00 & 23.3 & - & 18.68 & 1 & 19 & 8 & 19 & - & 28 \\
\hline & VSB-D & & 18.66 & 34.82 & 9.17 & 12.08 & 17.27 & 0 & 30 & 7 & 60 & 41 & 34 \\
\hline & SSB-R & & 31.13 & 44.23 & 32.2 & 24.75 & 29.90 & 0 & 14 & 9 & 12 & 20 & 16 \\
\hline & SSB-D & & 29.51 & - & 24.5 & 19.0 & 23.75 & 0 & 11 & - & 11 & 14 & 12 \\
\hline
\end{tabular}

Note: Concentration values of $\mathrm{Fe}$ and $\mathrm{Mn}$ are expressed in $\mathrm{mg} / \mathrm{L}$, and for the other elements in $\mu \mathrm{g} / \mathrm{L}$. Data below detection limit (DL) were replaced by $1 / 2$ of the DL value. Regul. - Regulations; SWC1 = maximum values for Class 1 fresh water (CONAMA 357/05). '' technique not applicable to the analyzed data set.

Using these methods, it is possible to estimate the threshold values of 5 to $6 \mathrm{mg} / \mathrm{L}$ and of 2 to $3 \mathrm{mg} / \mathrm{L}$ for total iron in both VSB and SSB in the rainy and dry seasons, respectively. This is apparently allowed by CONAMA 357/05. Mn, however, shows a distinct variation between VSB and SSB. In VSB, Mn behavior is similar to that of Fe, with decreasing threshold values from the rainy to the dry season. The opposite is seen in SSB, where threshold values for $\mathrm{Mn}$ show an accentuate independent of the geological setting as put in evidence by the similar threshold values in the two sub-basins.

$\mathrm{Mn}$ is the only metal that shows systematically values above the maximum valueincrease during the dry season (Table 3). In VSB, Mn threshold 
values can be estimated to be 0.35 to $0.45 \mathrm{mg} / \mathrm{L}$ in the raining season and 0.20 to $0.30 \mathrm{mg} / \mathrm{L}$ in the dry season. In SSB, threshold values increase from 0.3 to $0.4 \mathrm{mg} / \mathrm{L}$ in the rainy season to 1.3 to $1.4 \mathrm{mg} / \mathrm{L}$ in the dry season (Table 3 ).

\section{DISCUSSION}

\subsection{GEOCHEMICAL CHARACTERISTICS OF WATER}

During the rainy season, higher values of conductivity in the western part of VSB are probably related to a more intense leaching of nutrients and salts from multi-sources and are mainly controlled by the geology of the area (eastern border of the Amazonian Craton) through which the water flows. During the dry season, low conductivity stream waters occur mostly in the SSB, reflecting the combination of low rainfall with the local bedrock in this sub-basin dominated by geochemically depleted (meta)sedimentary rocks.

In relation to acidity $(\mathrm{pH})$, no significant trends were observed in stream water during both the rainy and dry seasons. The $\mathrm{pH}$ values are mostly neutral and fall within the admitted normal range for drinking water (Figure 3C). Few samples show accentuated acidity $(\mathrm{pH}<6.0)$ in the SSB during the dry season. These abnormal values were identified in four micro-catchments right next to each other, near an industrial area to the south of Marabá. This indicates that industrial activities possibly resulted in pollution emission that lowered the $\mathrm{pH}$ of water around that area.

The characteristics of the stream water for each catchment basin are better visualized in a plot of $\mathrm{pH}$ vs. the sum of base metals $(\mathrm{Zn}, \mathrm{Cu}, \mathrm{Pb}, \mathrm{Cd}$, $\mathrm{Co}$, and Ni). Stream waters of Vermelho and Sororó sub-basins are mostly near neutral and, except for a few samples, have low dissolved concentrations of these metals (Figure 6). However, if we consider $\mathrm{Fe}$ and $\mathrm{Mn}$, the total metal concentrations are classified as medium range, which demonstrates the strong influence of these two metals in local aqueous environment.
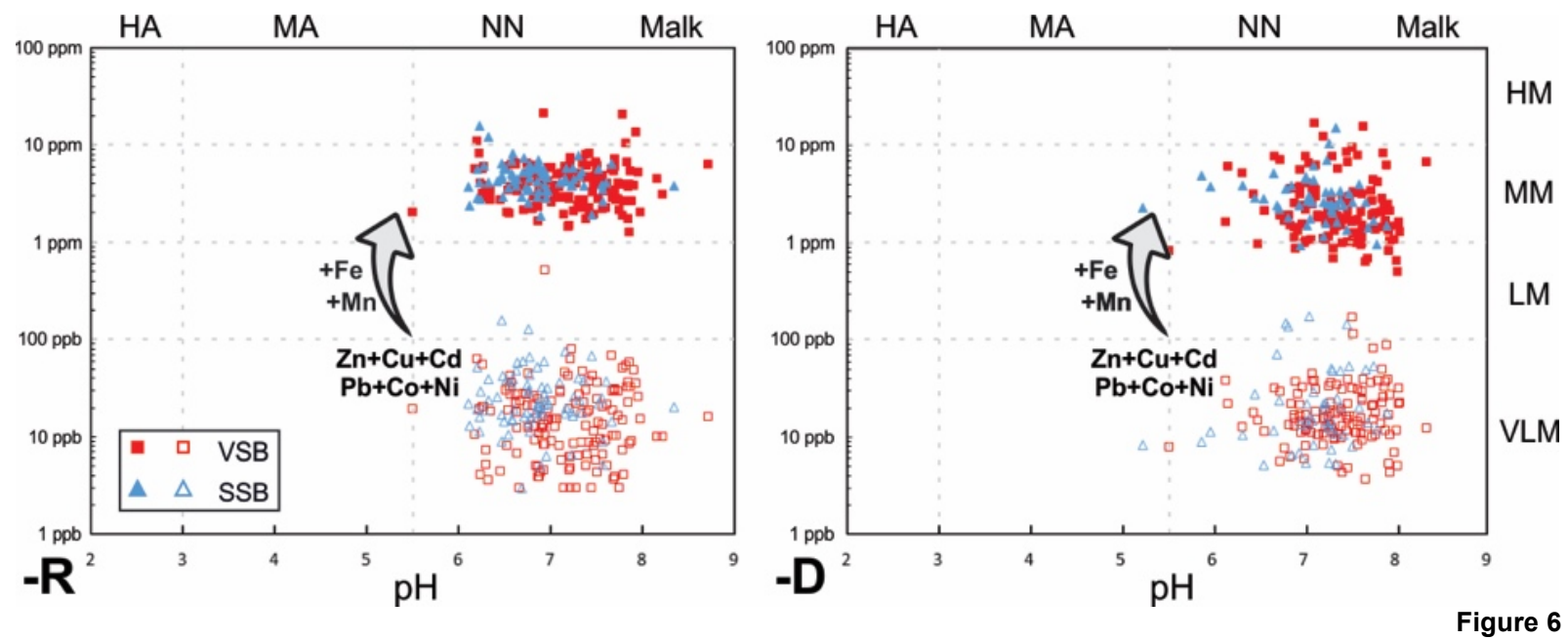

Modified Ficklin diagram of stream water samples showing the sum of dissolved base metal concentrations as a function of $\mathrm{pH}$ during the rainy (-R) and dry (-D) seasons in Vermelho (VSB) and Sororó (SSB) sub-basins. HA=High acid; MA=Medium acid; NN=Near neutral; Malk=moderate alkalinity; HM=High metallic; MM=Moderate metallic; LM=Low metallic; VLM=Very low metallic (modified from Macías et al. 2012)

\subsection{HIGH CONTENTS OF Fe AND Mn IN SURFICIAL WATER}

Irrespective of the season of the year, the concentrations of $\mathrm{Fe}$ followed by $\mathrm{Mn}$ in water of VSB and SSB were much higher when compared to the maximum value of CONAMA 357/05. Despite the occurrence of the Serra Leste iron mine in the extreme northeast of VSB (Figure 1), in the VSB and SSB, the influence of iron mines or deposits does not look relevant. The main course of Vermelho and Sororó rivers flows from south to north and their water characteristics are certainly more related to the geologic setting of the Araguaia Belt than to that of the Amazonian craton (Figures 1 and 2E). Hence, the anomalous geochemical behavior of Fe and $\mathrm{Mn}$ in the VSB and SSB and their high contents in the water cannot be explained by the influence of mining or banded-iron-formations, which are widespread only in the Archean terrains of the craton, and should be explained in other way. High $\mathrm{Fe}$ contents in surficial waters were also observed 
around the N3 and N4WSul areas in the Serra dos Carajás, studied by Teixeira (2016), but they are less common than in the VSB and SSB. Those areas are situated near the Fe mines of Serra Norte in the Carajás National Forest but water sampling was done in areas without direct influence of mining. Therefore, the higher Fe contents in water of those areas are also more likely related to local geogenic influence.

We admit that the enrichment in those elements in water is due to a sum of the conditions prevalent in most of the Amazonian region, thoroughly related to geologic setting associated with climatic and geomorphologic conditions. However, beside the mentioned factors, land use and land cover also exert influence in the geochemical distribution and mobility of these elements. Deforestation caused increase of water flow in the Itacaiúnas basin (Souza-Filho et al. 2016) and in the Amazonian region in general (Levy et al. 2018, Nóbrega et al. 2018) and it was particularly intense in the VSB and SSB (Figure 2A). It should favor the transport of metals concentrated in weathered rocks and ferruginous crusts to the water stream and this process should be particularly active during the rainy season, as put in evidence by our results. A similar situation was observed in other areas of the Itacaiúnas basin (Teixeira 2016). On the other hand, the increase of Mn content in water during the dry season could be due to release of $\mathrm{Mn}$ via biogeochemical processes that might be facilitated by low flows and consequent lesser water dilution during this period.

It is concluded that the maximum values proposed as reference in the Brazilian environmental legislation (CONAMA 357/05) for $\mathrm{Fe}$ and $\mathrm{Mn}$ are not realistic for the Amazonian region or at least for some regions of it. This contradictory situation is not specific of the Amazonian region and was verified also for several metals in other regions of Brazil (Rodriguez et al. 2013) or in other continents (Reimann et al. 2005). It suggests a need of more flexibility or adjustments of the legislation to the conditions prevailing in the Amazonia.

\subsection{NATURAL INFLUENCE VS. ANTHROPIC INFLUENCE AND ENVIRONMENTAL IMPLICATIONS}

For most elements, including $\mathrm{Co}, \mathrm{Cr}, \mathrm{Cu}, \mathrm{Ni}$, $\mathrm{Pb}, \mathrm{Sn}, \mathrm{V}$, and $\mathrm{Zn}$, the geogenic influence is clear as indicated by the contrast in metal distribution in the western area of the VSB included in the Archean Carajás Province of the Amazonian craton and other parts of the VSS and the entire SSB that corresponds to the Neoproterozoic Araguaia Belt. At the same time, for this same group of elements, the dominance of low metal contents in stream water is demonstrated by values $<\mathrm{DL}$. This aspect and the restrict number of analytical values above the maximum metal contents according to CONAMA 357/05 point to a subordinate anthropogenic influence in the studied area. In the cases of $\mathrm{Fe}$ and $\mathrm{Mn}$, the general picture is similar, but there is a significant difference. The intense change of land cover around the Vermelho and Sororó catchments with

\section{CONCLUSIONS}

- There are no accentuated variations in the physico-chemical parameters of water during the rainy and dry seasons in the VSB and SSB.

- For most of the analyzed metals, including As, $\mathrm{Co}, \mathrm{Cr}, \mathrm{Cu}, \mathrm{Ni}, \mathrm{Pb}, \mathrm{Sn}, \mathrm{V}$, and $\mathrm{Zn}$, the contents in surficial water are quite low and there is no evidence of significant contamination in the studied sub-basins. However, in general, these metals show higher contents in water during large scale replacement of tropical forest for pasturage has probably contributed to the increase of $\mathrm{Fe}$ and $\mathrm{Mn}$ contents in the stream water. In our view, the deforestation and replacement of tropical forest by pasturage lead to a remarkable anthropogenic effect that accentuated the natural influence of geological setting and lithologies associated with climatic and weathering processes that are characteristic of the Amazonian region. The contrast in $\mathrm{Fe}$ and $\mathrm{Mn}$ contents between the Vermelho and Sororo catchments located in the deforested eastern part of the Itacaiúnas basin and those obtained in stream water in areas situated in the Carajás National Forest, a preserved area (Teixeira 2016) are strong evidence of significant anthropic effects related to deforestation in the studied

area. the rainy season. This could be due to the increase of surficial flow that favors leaching and transport of metals to the local drainage.

- Fe and Mn contents in surficial water are high and their behavior differ from those of the other metals. The $\mathrm{Fe}$ distribution is not controlled by the occurrence of iron mines and banded-iron formations in the studied area. However, it was accentuated by the extensive 
deforestation in the VSB and SSB that favored intense leaching of exposed soils and weathered rocks. The increase of Mn contents during the dry season should be related to biogeochemical processes that were facilitated by the decrease of flow and water dilution during this period. High $\mathrm{Fe}$ and $\mathrm{Mn}$ contents in water are inherent to the natural conditions prevalent in the entire Amazonian region.

- The geogenic or natural influence in metal distribution in water is significant as indicated by differences in the concentrations of $\mathrm{Co}, \mathrm{Cr}$, $\mathrm{Cu}, \mathrm{Ni}, \mathrm{Pb}, \mathrm{Sn}, \mathrm{V}$, and $\mathrm{Zn}$, in the domain of the Amazonian craton compared to those in the Araguaia belt. Anthropogenic influence looks subordinate for most metals but it could be more significant in the case of $\mathrm{Fe}$ and $\mathrm{Mn}$, probably affected by the changes in land use and vegetation. Decrease in $\mathrm{pH}$ in areas near the industrial district of Marabá could also possibly result of anthropic influence.

\section{ACKNOWLEDGEMENTS}

This work is related to the Geochemical Background project, currently being undertaken at Instituto Tecnológico Vale (ITV). It was supported by: Vale (GABAN-DIFN); Conselho Nacional de Desenvolvimento Científico e Tecnológico (CNPq) [DTI scholarship to GNS (Proc. 380.418/2018-5); grants to RD (proc. 306108/2014-3; Proc. 443247/2015-3); and PWSF

\section{REFERENCES}

Almeida J.A.C., Dall'Agnol R., Oliveira M.A., Macambira M.J.B., Pimentel M.M., Rämö O.T., Guimarães F.V., Leite A.A.S. 2011. Zircon geochronology, geochemistry and origin of the TTG suites of the Rio Maria granite-greenstone terrane: Implications for the growth of the Archean crust of the Carajás province, Brazil. Precamb. Res., 187:201-221.

Alvarenga C.J.S., Moura C.A.V., Gorayeb P.S.S., Abreu F.A.M. 2000. Paraguay and Araguaia belts. In: U.G. Cordani, E.J. Milani, A. Thomas Filho, D.A. Campos (org.) Tectonic Evolution of South America. 31st International Geological Congress. p.: 183-193.

Alvares C.A., Stape J.L., Sentelhas P.C., Moraes Gonsalves J.L., Sparovek G. 2013. Koppen's climate classification map for Brazil. Meteorol. Zeitschrift, 22:711-728.

Ander E.L., Johnson C.C., Cave M.R., Palumbo-Roe B., Nathanail C.P., Lark R.M. 2013. Methodology for the determination of normal background concentrations of contaminants in English soil. Sci. Total Environ., 454-455:604-618.
- For those elements that presented a large proportion of data lower than DL, e.g. As, Co, $\mathrm{Cr}$, and $\mathrm{Pb}$, the definition of threshold values was limited and only indicative values were obtained. For $\mathrm{Cu}, \mathrm{Ni}, \mathrm{Sn}, \mathrm{V}$, and $\mathrm{Zn}$ threshold values for at least one season were estimated in each sub-basin. In the case of $\mathrm{Fe}$ and $\mathrm{Mn}$, the methods $\mathrm{I}-2 \sigma$ and DF were selected for geochemical threshold estimation. Values of 5 to $6 \mathrm{mg} / \mathrm{L}$ and of 2 to $3 \mathrm{mg} / \mathrm{L}$ for total iron were obtained in both VSB and SSB in the rainy and dry seasons, respectively. $\mathrm{Mn}$ behavior is distinct in VSB and SSB. In VSB, estimated Mn threshold values are 0.35 to 0.45 $\mathrm{mg} / \mathrm{L}$ in the raining season and 0.20 to 0.30 $\mathrm{mg} / \mathrm{L}$ in the dry season. In SSB, threshold values increase from 0.3 to $0.4 \mathrm{mg} / \mathrm{L}$ in the rainy season to 1.3 to $1.4 \mathrm{mg} / \mathrm{L}$ in the dry season. It is concluded that threshold values for metals are mostly low, except for Fe and $\mathrm{Mn}$ which behavior is controlled by the regional environment.

(306450/2013-5)]. The authors acknowledge Otavio A. B. Licht for invitation to contribute to this volume and for editorial handling and, for collaboration with the Background project, himself, Rômulo S. Angelica, Carlos Augusto de Medeiros Filho, Marcondes L. da Costa e José Francisco P. Ramos.

APHA - American Public Health Association. 2012. Standard methods for the examination of water and wastewater, 22nd ed. American Public Health Association, Washington, $1360 \mathrm{pp}$.

Araújo O.J.B., Maia R.G. 1991. Serra dos Carajás. SB.22-Z-A. Brasília, DF, DNPM/CPRM. Mapa Geológico, escala 1:250.000.

Arpine H. \& Gayane S. 2016. Determination of background concentrations of hydrochemical parameters and water quality assessment in the Akhuryan River Basin (Armenia). Phys. Chem. Earth, 94:2-9.

Aubert A.H., Kirchner J.W., Gascuel-Odoux C., Faucheux M., Gruau G., Mérot P. 2014. Fractal water quality fluctuations spanning the periodic table in an intensively farmed watershed. Environ. Sci. Technol., 48:930-937.

Barros C.E.M., Macambira M.J.B., Barbey P. 2001. Idade de zircões do Complexo Granítico Estrela: relações entre magmatismo, deformação e metamorfismo na Província Metalogenética de Carajás. In: SBG, Simpósio de Geologia da Amazônia, 7, Anais. 
BRASIL. Ministério do Meio Ambiente. Resolução CONAMA n ${ }^{\circ} 357$, de 17 de março de 2005. Dispõe sobre a classificação dos corpos de água e diretrizes ambientais para o seu enquadramento, bem como estabelece as condições e padrões de lançamento de efluentes, e dá outras providências. Diário Oficial [da] República Federativa do Brasil. Brasília, DF, 18 mar. 2005. Disponível em: <http: http://www.mma.gov.br/port/conama/res/res05/res3 5705.pdf $>$ Accessed in 15 apr. 2018.

Brion G., Brye K.R., Haggard B.E., West C., Brahana J.V. 2011. Land-use effects on water quality of a first-order stream in the Ozark Highlands, midsouthern United States. River. Res. Appl., 27:772790.

Cembranel A.S., Sampaio S.C., Remor M.B., Gotardo J.T., Dalla Rosa P.M. 2017. Geochemical background in an oxisol. Eng. Agric. 37:565-573.

CPRM - COMPANHIA DE PESQUISA DE RECURSOS MINERAIS 2012. Projeto avaliação do potencial dos recursos minerais estratégicos do Brasil: área Carajás Oriental. Disponível em http://geowebapp.cprm.gov.br/ViewerWEB/index geoquimica.html. Accessed in 12 jun 2017.

CPRM - COMPANHIA DE PESQUISA DE RECURSOS MINERAIS 2013. Projeto metalogenia das províncias minerais do Brasil: área Sapucaia. Disponível em http://geowebapp.cprm.gov.br/ViewerWEB/index_ geoquimica.html. Accessed in 12 jun 2017.

Dall'Agnol R., Cunha I.R.V., Guimarães F.V., Oliveira D.C., Teixeira M.F.B., Feio G.R.L., Lamarão C.N. 2017. Mineralogy, geochemistry, and petrology of Neoarchean ferroan to magnesian granites of Carajás Province, Amazonian Craton: The origin of hydrated granites associated with charnockites. Lithos, 277:3-32.

Dall'Agnol R., Teixeira N.P., Macambira J.B., Kotschoubey B., Gorayeb P.S.S., Santos M.D. 1988. Petrologia dos gnaisses e micaxistos da porção norte da Faixa de Dobramentos Araguaia, Goiás-Brasil. In: SBG, Congresso LatinoAmericano de Geologia, 7, Anais, p. 1-19.

Docegeo - RIO DOCE GEOLOGIA E MINERAÇÃO S.A. 1988. Revisão litoestratigráfica da Província Mineral de Carajás. In: SBG, Congr. Bras. Geol., 35, Anais, p. 11-59.

Equipe Estatcamp 2014. Software Action Stat, version Pro: Estatcamp - Consultoria em estatística e qualidade. São Carlos, SP. Disponível em: http://www.portalaction.com.br/. Accessed in 8 may 2018.

Feio G.R.L., Dall'Agnol R., Dantas E.L., Macambira M.J.B., Gomes A.C.B., Sardinha A.S., Oliveira D.C., Santos R.D., Santos P.A. 2012. Geochemistry, geochronology, and origin of the Neoarchean Planalto Granite suite, Carajás, Amazonian craton: A-type or hydrated charnockitic granites? Lithos, 151:57-73.

Feio G.R.L., Dall'Agnol R., Dantas E.L., Macambira M.J.B., Santos J.O.S., Althoff F.J., Soares J.E.B. 2013. Archean granitoid magmatism in the Canaã dos Carajás area: Implications for crustal evolution of the Carajás province, Amazonian craton, Brazil. Precambrian Res., 227:157-185.

Gałuszka A. \& Migaszewski Z.M. 2012. Geochemical background - an environmental perspective. Mineralogia, 42:7-17.

Gałuszka A. 2007. Different approaches in using and understanding the term "Geochemical background" - Practical implications for environmental studies. Polish J. Environ. Stud., 16:389-395.

Gibbs A.K., Wirth K.R., Hirata K.H., Olszewski Junior W.J. 1986. Age and composition of the Grao Para Group volcanics, Serra dos Carajas, Brazil. Rev. Bras. Geoc., 16:201-211.

Girardi R., Pinheiro A., Garbossa L.H.P., Torres É. 2016. Water quality change of rivers during rainy events in a watershed with different land uses in Southern Brazil. Ver. Bras. Recur. Hídricos, 21:514-524.

Gorayeb P.S.S. 1981. Evolução geológica da região de Araguacema-Pequizeiro (GO), Brasil. Dissertação de Mestrado, Centro de Geociências, Universidade Federal do Pará, 99 p.

Grubbs F.E. 1969. Procedures for Detecting Outlying Observations in Samples. Technometrics, 11:1-21.

Halliday S.J., Skeffington R.A., Wade A.J., Bowes M.J., Gozzard E., Newman J.R., Loewenthal M., Palmer-Felgate E.J., Jarvie H.P. 2015. Highfrequency water quality monitoring in an urban catchment: hydrochemical dynamics, primary production and implications for the Water Framework Directive. Hydrol. Process., 29:33883407.

Hasui Y., Costa J.B.S., Abreu F.A.M. 1984. Província Tocantins-Setor setentrional. In: F.F.A. Almeida \& Y. Hasui (org.) O Precambriano no Brasil. Edgard Blucher. p. 137-204.

Huhn S.R.B., Macambira M.J.B., Dall'Agnol R. 1999. Geologia e Geocronologia $\mathrm{Pb} / \mathrm{Pb}$ do Granito Alcalino Arqueano Planalto, Região da Serra do Rabo - Carajás-PA. In: SBG, Simp. Geol. da Amaz., 6, Anais, p. 463-466.

Keith L.H., Crummett W., Deegan J., Libby R.A., Taylor J.K., Wentler G. 1983. Principles of environmental analysis. Anal. Chem., 55:2210 2218.

Levy M.C., Lopes A.V., Cohn A., Larsen L.G., Thompson S.E. 2018. Land use change increases streamflow across the arc of deforestation in Brazil. Geophys. Res. Lett., 45:1-11.

Machado N., Lindenmayer Z., Krogh T.H., Lindenmayer Z.G. 1991. U-Pb geochronology of Archaean magmatism and basement reactivation in the Carajás area, Amazon shield, Brazil. Precambrian Res., 49:329-354.

Macías F., Caraballo M.A., Rötting T.S., Pérez-López R., Nieto J.M., Ayora C. 2012. From highly polluted $\mathrm{Zn}$-rich acid mine drainage to non-metallic waters: Implementation of a multi-step alkaline passive treatment system to remediate metal pollution. Sci Total Environ., 433:323-330.

Martins P.L.G., Toledo C.L.B., Silva A.M., Chemale F., Santos J.O.S., Assis L.M. 2017. Neoarchean magmatism in the southeastern Amazonian Craton, 
Brazil: Petrography, geochemistry and tectonic significance of basalts from the Carajás Basin. Precambrian Res., 302:340-357.

Matschullat J., Ottenstein R., Reimann C. 2000. Geochemical background-can we calculate it? Environ Geol., 39:990-1000.

Moreto C.P.N., Monteiro L.V.S., Xavier R.P., Creaser R.A., DuFrane S.A., Melo G.H.C., Silva M.A.D., Tassinari C.C.G., Sato K. 2014. Timing of multiple hydrothermal events in the iron oxide-copper-gold deposits of the Southern Copper Belt, Carajás Province, Brazil. Miner. Depos., 50:517-546.

Nakić Z., Posavec K., Bačani A. 2007. A visual basic spreadsheet macro for geochemical background analysis. Ground Water., 45:642-647.

Nakić Z., Posavec K., Parlov J. 2010. Model-based objective methods for the estimation of groundwater geochemical background. AQUAmundi., 1:65-72.

Neal C., Reynolds B., Rowland P., Norris D., Kirchner J.W., Neal M., Sleep D., Lawlor A., Woods C., Thacker S., Guyatt H., Vincent C., Hockenhull K., Wickham H., Harman S., Armstrong L. 2012. High-frequency water quality time series in precipitation and streamflow: From fragmentary signals to scientific challenge. Sci. Total Environ., 434:3-12.

Nóbrega R.L.B., Lamparter G., Hughes H., Guzha A.C., Amorim R.S.S., Gerold G. 2018. A multiapproach and multi-scale study on water quantity and quality changes in the Tapajós River basin, Amazon. Proc. Int. Assoc. Hydrol. Sci., 377:3-7.

Nogueira A.C.R., Truckenbrodt W., Pinheiro R.V.L. 1995. Formação Águas Claras, Pré-Cambriano da Serra dos Carajás: redescrição e redefinição litoestratigráfica. Bol. Mus. Para. Emilio Goeldi Cienc. Nat., 7:177-197.

Outram F.N., Lloyd C.E.M., Jonczyk J., Benskin McW.H., Grant F., Perks M.T., Deasy C., Burke S.P., Collins A.L., Freer J., Haygarth P.M., Hiscock K.M., Johnes P.J., Lovett A.L. 2014. Highfrequency monitoring of nitrogen and phosphorus response in three rural catchments to the end of the 2011-2012 drought in England. Hydrol. Earth. Syst. Sci., 18:3429-3448.

Peh Z., Miko S., Hasan O. 2009. Geochemical background in soils: A linear process domain? An example from Istria (Croatia). Environ. Earth Sci., 59:1367-1383.

Pimentel M.M., Fuck R.A., Jost H. 2004. O embasamento da Faixa Brasília e o Arco Magmático de Goiás. In: V. Mantesso-Neto, A. Bartorelli, C. Dal Re Carneiro, B.B. Brito Neves (org.) Geologia do Continente Sul-Americano Evolução da Obra de Fernando Flávio Marques de Almeida. Beca Producões Culturais Ltda, São Paulo, p. 355-368.

Quantum GIS Development Team 2009. Quantum GIS Geographic Information System. Open Source Geospatial Foundation Project, version 3.0. Disponível em: http://grass.osgeo.org. Acessado em 8 maio 2018.

R Development Core Team 2008. R: A language and environment for statistical computing. $\mathrm{R}$ Foundation for Statistical Computing, version 3.3.3. Vienna, AT, ISBN 3-900051-07-0. Disponível em: http://www.R-project.org. Accessed in 8 may 2018.

Reimann C. \& Caritat P. 2017. Establishing geochemical background variation and threshold values for 59 elements in Australian surface soil. Sci. Total Environ., 578:633-648.

Reimann C. \& Garrett R.G. 2005. Geochemical background - Concept and reality. Sci. Total Environ. 350:12-27.

Reimann C., Fabian K., Birke M., Filzmoser P., Demetriades A., Négrel P., Oorts K., Matschullat J., Caritat P., The GEMAS Project Team. 2018. GEMAS: Establishing geochemical background and threshold for 53 chemical elements in European agricultural soil. Appl. Geoch., 88:302-318.

Reimann C., Filzmoser P., Garrett R.G. 2005. Background and threshold: critical comparison of methods of determination. Sci. Total Environ., 346:1-16.

Rodrigues A.S.L., Malafaia G., Costa A.T., Nalini Júnior H.A. 2013. Background values for chemical elements in sediments of the Gualaxo do Norte River Basin, MG, Brazil. Ver. Ciênc. Amb., 7:1532.

Ruivo M.L.P. \& Sales M.E.C. 1989. Monitoramento da qualidade da água na área do projeto Ferro Carajás - Um subsídio para o estudo ambiental. Bol. Mus. Para. Emilio Goeldi Cienc. da Terra, 1:11-24.

Sardinha A.S., Barros C.E.M., Krymsky R. 2006. Geology, geochemistry, and $\mathrm{U}-\mathrm{Pb}$ geochronology of the Archean $(2.74 \mathrm{Ga})$ Serra do Rabo granite stocks, Carajás Metallogenetic Province, northern Brazil. Journ. South Am. Earth Sci., 20:327-339.

Silva Júnior R.O., Souza E.B., Tavares A.L., Mota J.A., Ferreira D.B.S., Souza-Filho P.W.M., Rocha E.J.P. 2017. Three decades of reference evapotranspiration estimates for a tropical watershed in the eastern Amazon. Anais da Acad. Bras. Cienc., 89:1985-2002.

Souza-Filho P.W.M., Souza E.B., Silva Júnior R.O., Nascimento Júnior W.R., Mendonça B.R.V., Guimarães J.T.F., Dall'Agnol R., Siqueira J.O. 2016. Four decades of land-cover, land-use and hydroclimatology changes in the Itacaiúnas River watershed, southeastern Amazon. Journ. Environ. Manage., 167:175-184.

Teixeira A.S., Ferreira Filho C.F., Giustina M.E.S.D., Araújo S.M., Silva H.H.A.B. 2015. Geology, petrology and geochronology of the Lago Grande layered complex: Evidence for a PGE-mineralized magmatic suite in the Carajás Mineral Province, Brazil. Journ. South Am. Earth Sci., 64:116-138.

Teixeira M.F.B., Dall'Agnol R., Santos J.O.S., Sousa L.A.M., Lafon J.M. 2017. Geochemistry, geochronology and $\mathrm{Nd}$ isotopes of the Gogó da Onça Granite: a new Paleoproterozoic A-type granite of Carajás Province, Brazil. In: SBG, Simp. Geol. da Amaz., 15, Anais.

Teixeira S.S. 2016. Estudo da qualidade das águas superficiais e estimativa de background na área das minas de ferro da Serra Norte, Carajás. Dissertação 
de Mestrado, Instituto Tecnológico Vale, 128 p.

Teng Y., Ni S., Wang J., Niu L. 2009. Geochemical baseline of trace elements in the sediment in Dexing area, South China. Environ. Geol., 57:1649-1660.

Tercier-Waeber M.L., Hezard T., Masson M., Schäfer J. 2009. In situ monitoring of the diurnal cycling of dynamic metal species in a stream under contrasting photobenthic biofilm activity and hydrological conditions. Environ. Sci. Technol., 43:7237-7244.

Urresti-Estala B., Carrasco-Cantos F., Vadillo-Pérez I., Jiménez-Gavilán P. 2013. Determination of background levels on water quality of groundwater bodies: A methodological proposal applied to a Mediterranean River basin (Guadalhorce River, Málaga, southern Spain). Journ. Environ. Manage., 117:121-130.

Vasquez M.L., Sousa C.S., Carvalho K.M.A. 2008. Geologia e recursos minerais do estado do Pará: texto explicativo. Belém, CPRM, 1 mapa geológico, escala 1:1.000.000.

Wade A.J., Palmer-Felgate E.J., Halliday S.J., Skeffington R.A., Loewenthal M., Jarvie H.P., Bowes M.J., Greenway G.M., Haswell S.J., Bell I.M., Joly E., Fallatah A., Neal C., Williams R.J., Gozzard E., Newman J.R. 2012. Hydrochemical processes in lowland rivers: Insights from in situ, high-resolution monitoring. Hydrol. Earth Syst. Sci., 16:4323-4342.

Zgłobicki W., Lata L., Plak A., Reszka M. 2011. Geochemical and statistical approach to evaluate background concentrations of $\mathrm{Cd}, \mathrm{Cu}, \mathrm{Pb}$ and $\mathrm{Zn}$ (case study: Eastern Poland). Environ. Earth Sci., 62:347-355.

Zucchetti M. \& Lobato L.M. 2004. Alteração hidrotermal a ferro das rochas máficas associadas aos depósitos de ferro N4 e N5, província mineral de Carajás, PA. In: SBG, Simp. Bras. Explor. Miner., 3, Anais. 